\title{
Individual rail transport and the conception of a means of transport using a suspended railway track
}

\begin{abstract}
Distances to cover are still growing in Polish coal mines. It is not a real issue in terms of material and staff transport, which commonly uses suspended monorails with a friction wheel drive. The problem is how to transfer single people and small loads behind the scheduled times and routes of monorails.

The goal of this work was to design and construct an individual mean of transport with its own drive using a monorail track which would meet the requirements of law, safety, mobility and can be used behind the scheduled times of monorails.
\end{abstract}

Key words: suspended bike, individual mean of underground transport

\section{INTRODUCTION}

This article about individual means of transport which could be used in underground workings, as well as works on its construction, started with considerations on the history of bicycles and rail transport.

The beginning of bicycle history is dated to 12 June 1817 in Mannheim, when Karl Drais demonstrated his balance bike, called "Draisine", which in a short period of time revolutionized individual transport (Fig. 1).
The invention was a subject of numerous modifications, thanks to which todays bicycle received its current shape. Because of the rising popularity, simplicity and reliability of bicycles, in 1892 after bike's redesign, it was adapted for suspended rail rides and was used as an individual means of municipal transport $[1,2]$.

Figure 2 presents a suspended monorail bicycle on a purpose-built line connecting Mount Holly with Smithville in New Jersey, USA. It was invented by Arthur E. Hotchkiss and it was built in 1892 .

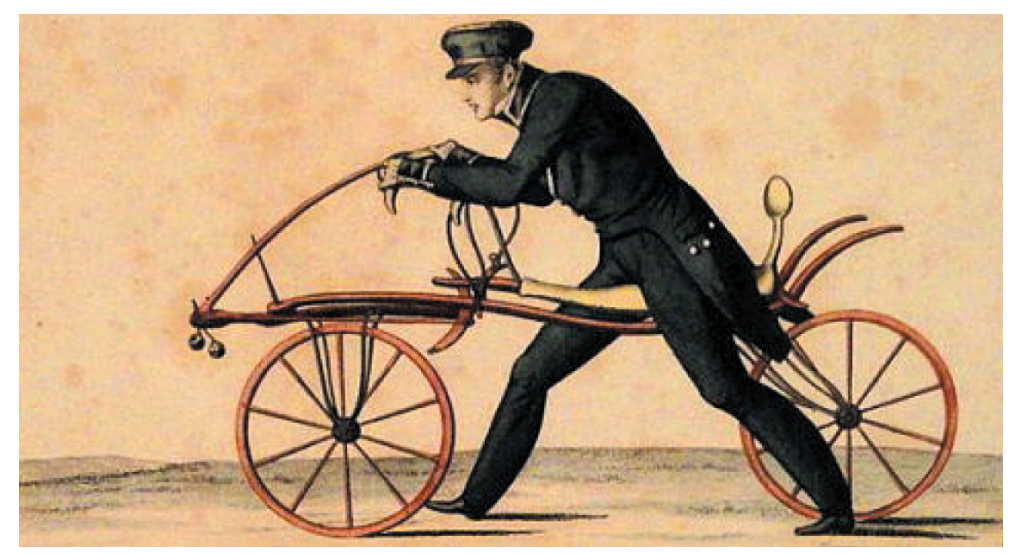

Fig. 1. "Draisine", Karl Drais' balance bike [3] 


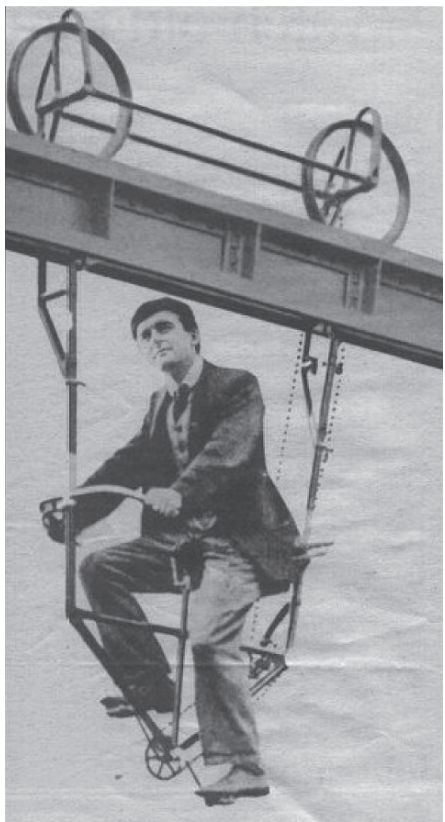

Fig. 2. Suspended monorail bike [4]

This special line was dedicated for workers who had to commute to the factory in Smithville. Workers who wanted to commute were supposed to borrow a bike which was available in storage situated along the rail route. The main disadvantages of the project mentioned above were lack of possibilities to overtake other riders and the need to use one line for riding in both directions, because the second line was never built. In the case of heavy traffic, it significantly slows the transport down $[4,5]$.

\section{Monorail transport}

A relatively new means of transport are monorail systems. Their origins are dated on the beginning of $19^{\text {th }}$ century. They can be divided in two groups: suspended systems (Fig. 2) and systems in which a means of transport is situated on the rail (Fig. 3). The origin of monorail transport usage dates back to 1820 , when the inventor Iwan Elmanow developed an elevated single-track railway line. Horses pulled trolleys on wooden rails (the horses moved along the rail). Because of the simplicity of this idea, it gained in popularity and the invention was adapted as a means of transport for miners in Crimean salt mines [7, 8].

Another Russian inventor, Belozersky, proposed a railway system in 1836 with two rows of wheels which was built on column structure. In 1872 the Łuszczski monorail railway was developed and it was presented at a polytechnical exhibition in Moscow and in 1874 the construction of Aleksji Chludow's monorail railway, dedicated to timber transport, began.

Monorail systems developed dynamically not only in Russia but also in other parts of the world. One of the most famous pioneers of monorail technology was the engineer Henry Robinson Palmer, who patented the concept of the monorail in 1821 (GB nr 4618). A line was constructed in Deptford Quays in London in 1824, and in June 1825 a monorail was launched in Cheshunt intended for brick transport. Wooden carriages hung under the rail and were pulled by horses. Friedrich Harkort worked on the development of rail transport in Germany, and his aim was to build a demonstrative route between Elberfeld and Barmen, districts of the German industrial town of Elberfeld. In 1827 Harkort improved Palmer's railway - instead of horses he used steam engines. In subsequent years, the concept developed further and the effects of improvement can be observed in example of Wuppertaler Schwebebahn railway, which was installed in Wuppertal and is still functioning as the longest suspended railway line in the world, connecting the Oberbarmen and Vohwinkel districts (Fig. 4) [1].

The division of monorails into external and own drive devices was caused by differences in their construction. A historical example of a monorail is the Bicycle Railroad, constructed by Arthur Hotchkiss from New Haven, New England (Fig. 5). His invention was patented in December 1892 (US 488.201) [5].

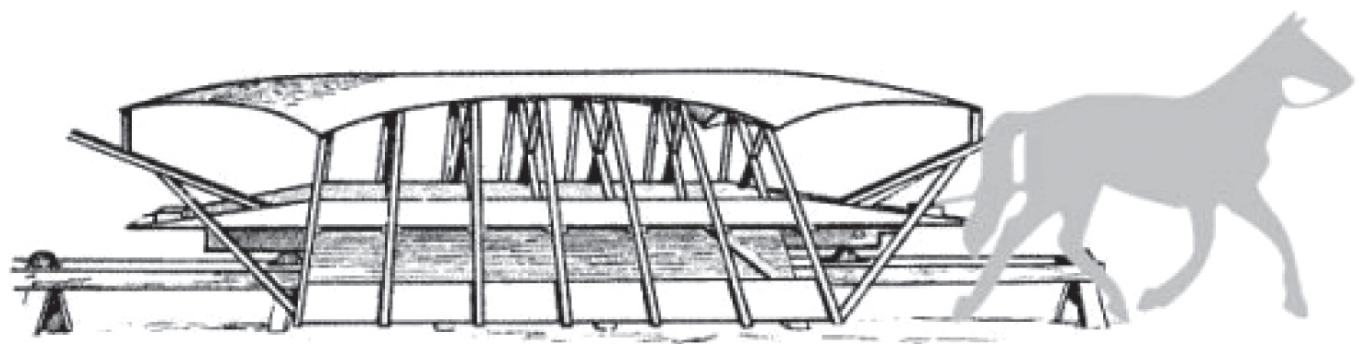

Fig. 3. Iwan Elmanow's monorail single-track railway solution [8] 


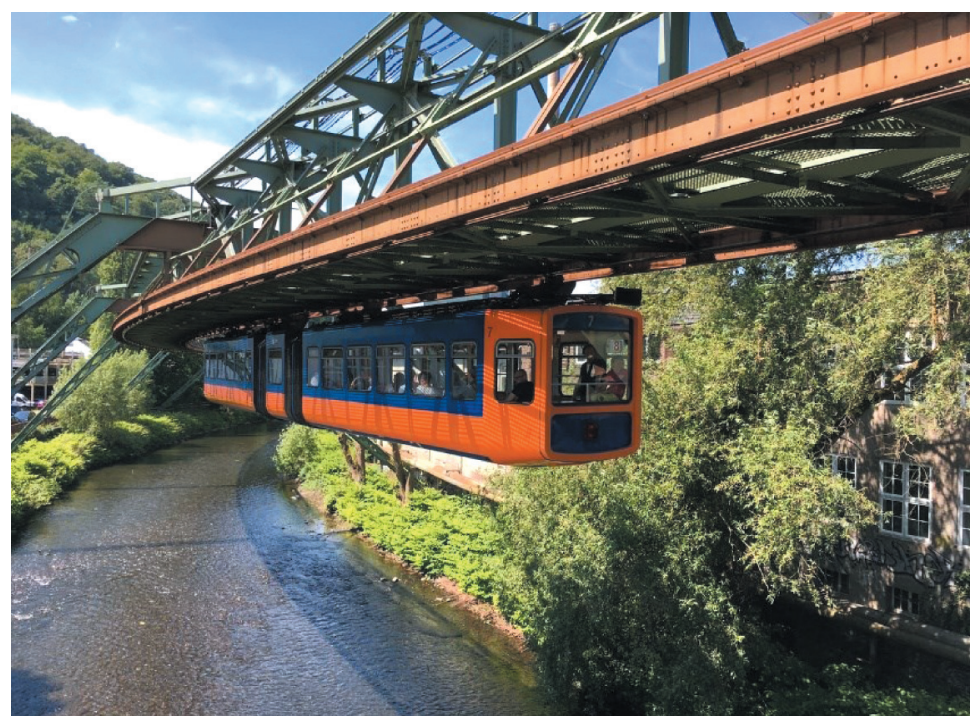

Fig. 4. Wuppertaler Schwebebahn railway [3]
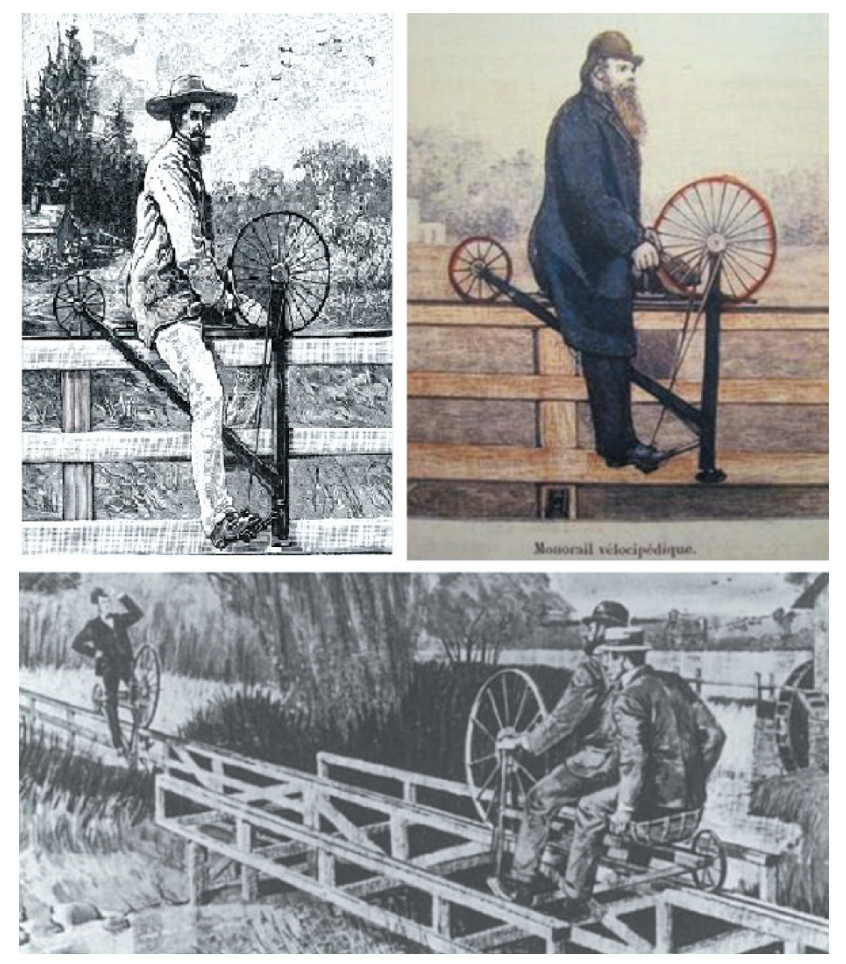

Fig. 5. Bicycle railroad [4]

\subsection{Historical application of bicycles as individual means of transport in underground mining}

The dynamic growth of industry at the turn of $19^{\text {th }}$ and early $20^{\text {th }}$ century caused a rise in demand for hard coal as a basic energy resource. Rising coal production was a reason for collieries development, which in turn entailed the elongation of the distance between the main shaft and working place of miners. A result of this situation was the rapid development of improvised means of underground transport.
Mines management adapted means of transport to underground application which were typically used on the surface. One of the most popular and commonly used underground individual transport devices was the bike (widely in use in German and Dutch mines). In the beginning, the miner's bike was produced in short series by the mines themselves, because of no existing bike producer. In 1954, the first serial miner's bike Grubenflitzer, was introduced by Scharf GmbH from Hamm, Germany. Brochure and logo of this product is shown in Figure 6 [9-11]. 

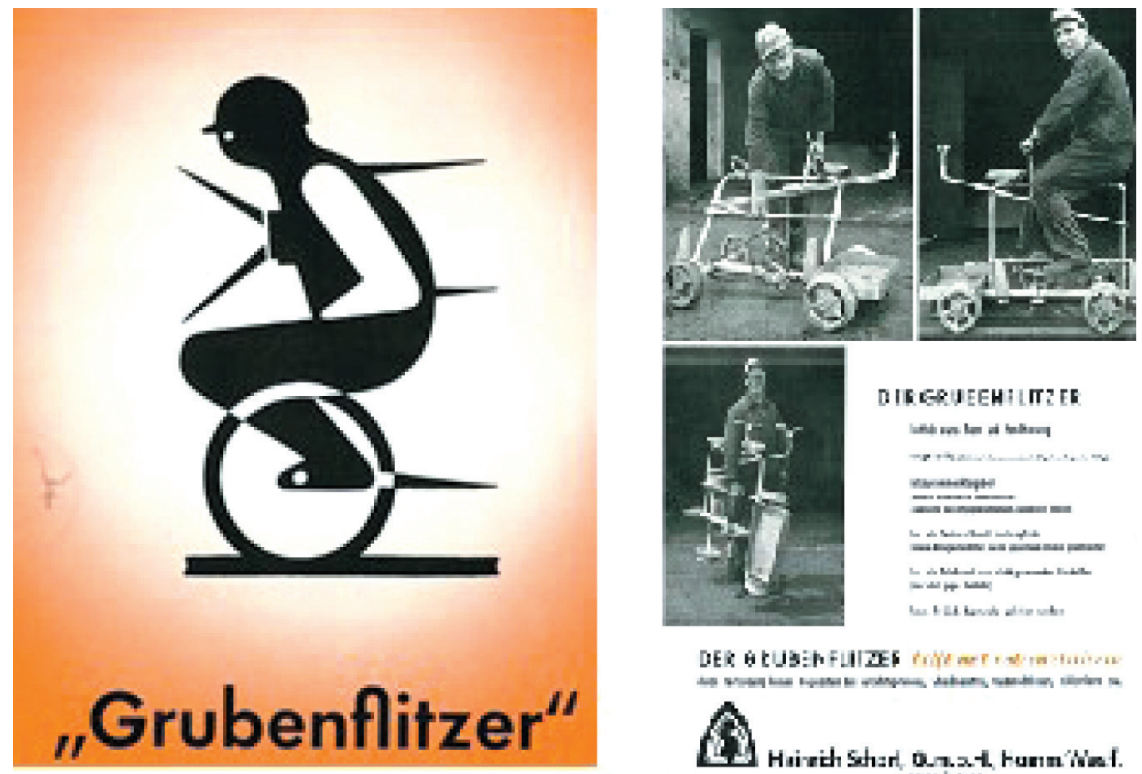

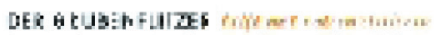

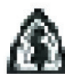

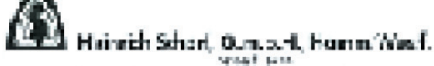

Fig. 6. Logo and brochure of Grubenflitzer, first miner's bike [11]

Grubenflitzer's target were mine workers whose job characteristics caused a need for frequent communication between different underground workings, e.g. mine supervisors, carpenters, electricians etc. The prototype was a simple, small construction with a cargo box placed in the back. The vehicle was noticed by West Germany's federal Minister of Economy, Erhard, at a mining fair in Essen in 1954. In the following years, sales of the miner's bike varied between 30 and 40 vehicles per month. It was also developed to fit the different needs of buyers, e.g. variants of a bike were introduced - made to fit various working dimensions, equipped with toolboxes or made of a AlMgSi alloy, which is corrosion resistant and light- er than steel, the result of which was a weight reduction to only $30 \mathrm{~kg}$.

Numerous types of miner's bike were introduced in accordance with miners' needs. Their features varied depending on the workings parameters, daily distances to cover or the bike's capacity. Some of these types are presented below.

The basic model produced by Scharf $\mathrm{GmbH}$ was the Zg-Nr. 35003-00.00 miner's bike (Fig. 7) made of aluminum with a folding frame, in versions with two saddles and one toolbox, one saddle and one toolbox or one saddle and two toolboxes, while bike model S-35017 was equipped with two toolboxes and two saddles. Basic technical data are presented in Table 1 and Figure 7 [6].
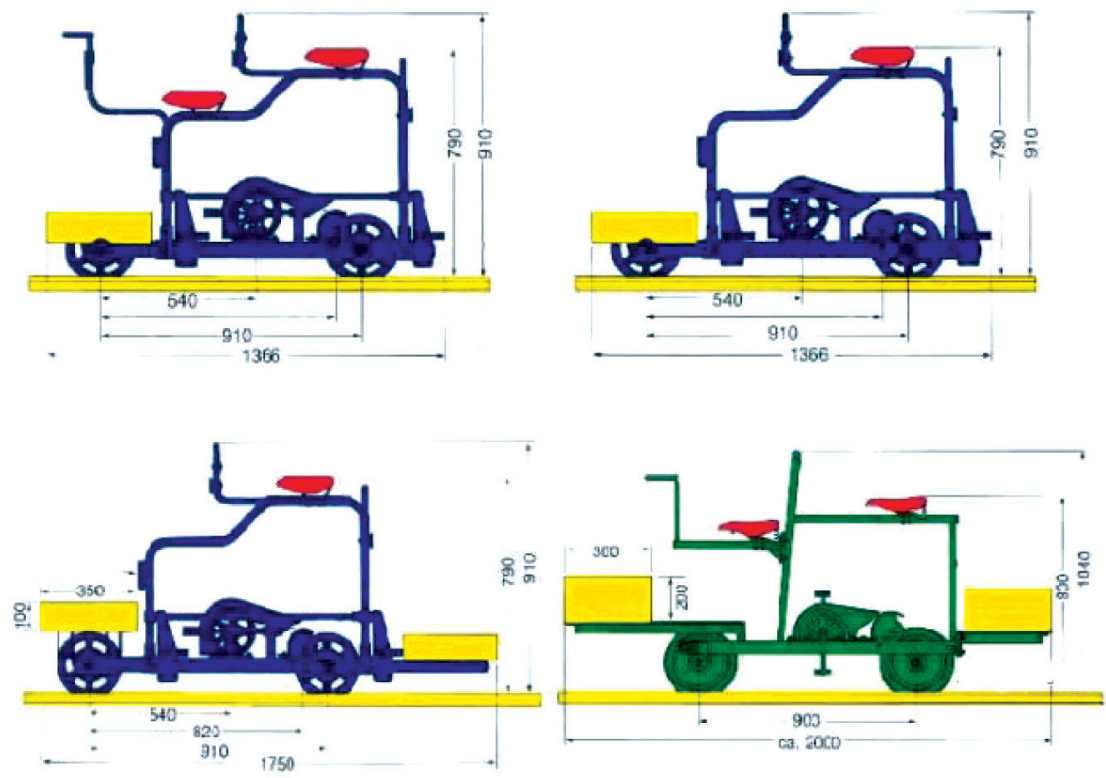

Fig. 7. Basic model of miner's bike in different versions [6] 
Table 1

Basic technical data of the Zg-Nr. 35005-00.00 and Zg-Nr. S-35017 bike models (Fig. 7) [6]

\begin{tabular}{|l|c|c|}
\hline \multicolumn{1}{|c|}{ Model } & Zg-Nr. 35003-00.00 & Zg.-Nr. S-35017 \\
\hline Total length $[\mathrm{mm}]$ & 1366 & 2000 \\
\hline Height $[\mathrm{mm}]$ & 910 & 1040 \\
\hline Curbweight $[\mathrm{kg}]$ & 50 & 100 \\
\hline Payload $[\mathrm{kg}]$ & 200 & 250 \\
\hline
\end{tabular}

The next model was equipped with a toolbox in front of the bike and carriage with three-pointed bearing to avoid derailing of the vehicle even in bad trackway conditions. In case of tight spaces in the workings, the bike could be easily folded. Furthermore, to create some pieces of the bike, producers used corrosion resistant alloy 6060 (EN AW-AlMgSi), which resulted in decreasing the prototype's mass.
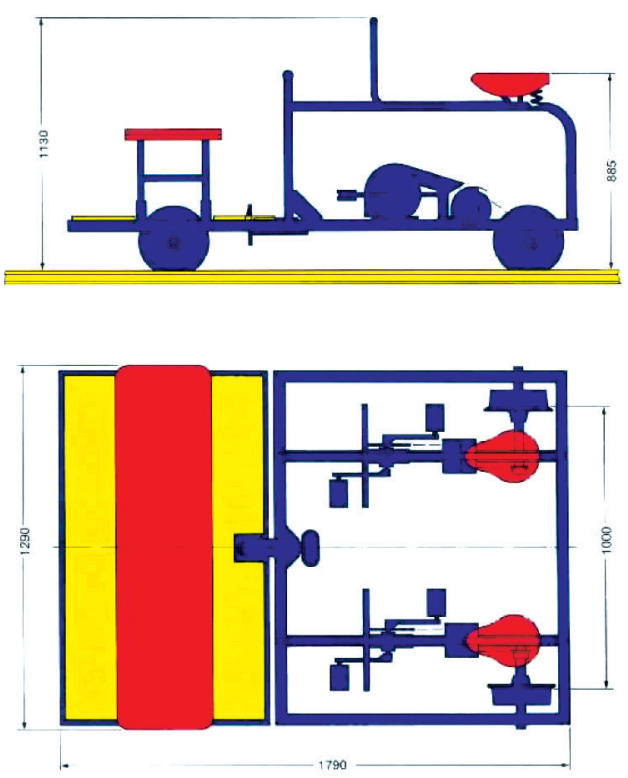

Fig. 8. Five-person emergency bike Zg-Nr-S-135016 [6]

This vehicle was produced especially for short-distance rides. It was equipped with two bucket seats placed next to each other, two drives and tool-box placed in front of the bike. The highest part of the bike was the top edge of the bucket seat. There was also the option of attaching a trailer to the bike, the trailer was $680 \mathrm{~mm}$ high and weighed $42 \mathrm{~kg}$. The basic technical information of the bike and the trailer is shown in Figure 9, Tables 3 and 4.

There is no doubt that during a period which saw a low level of mechanization in mining, the miner's bike had a great impact on the development of the

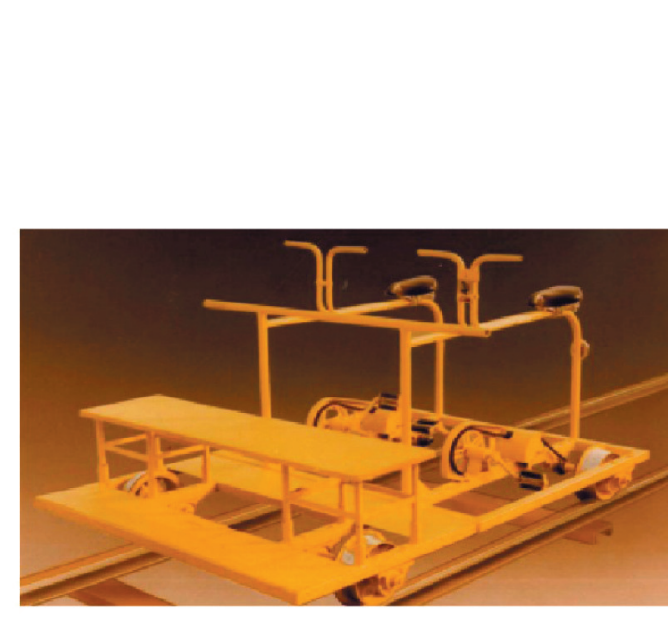

Bike model $\mathrm{Zg}-\mathrm{Nr}$ S-135016 was designed as an emergency vehicle. This type of vehicle was used in rides with distances longer than $5000 \mathrm{~m}$. It was equipped with two drives, a coaster brake and a bench on which three people could sit. The basic specification is presented in Table 2 and Figure $8[6,12]$.

Table 2

Basic technical information about the

Zg-Nr S-135016 five-person emergency bike (Fig. 8) [6]

\begin{tabular}{|l|c|}
\hline \multicolumn{1}{|c|}{ Model } & Zg-Nr. S-135016 \\
\hline Total length $[\mathrm{mm}]$ & 1790 \\
\hline Height $[\mathrm{mm}]$ & 130 \\
\hline Curb weight $[\mathrm{kg}]$ & 130 \\
\hline Payload $[\mathrm{kg}]$ & 600 \\
\hline
\end{tabular}

whole industry by extending effective worktime. It was possible by shortening the time of transport between distant workings. In subsequent years, the growing number of vehicles and other machines operating in mine workings made bike usage hazardous for miners. It is also important to note that in the first years of their operation, there were no legal restrictions on bikes but that this changed in the following years. For example, the application of aluminum in underground machines was forbidden and the need for bikes to be equipped with lights became a legally requirement, which in turn led to an increase in weight [6]. 


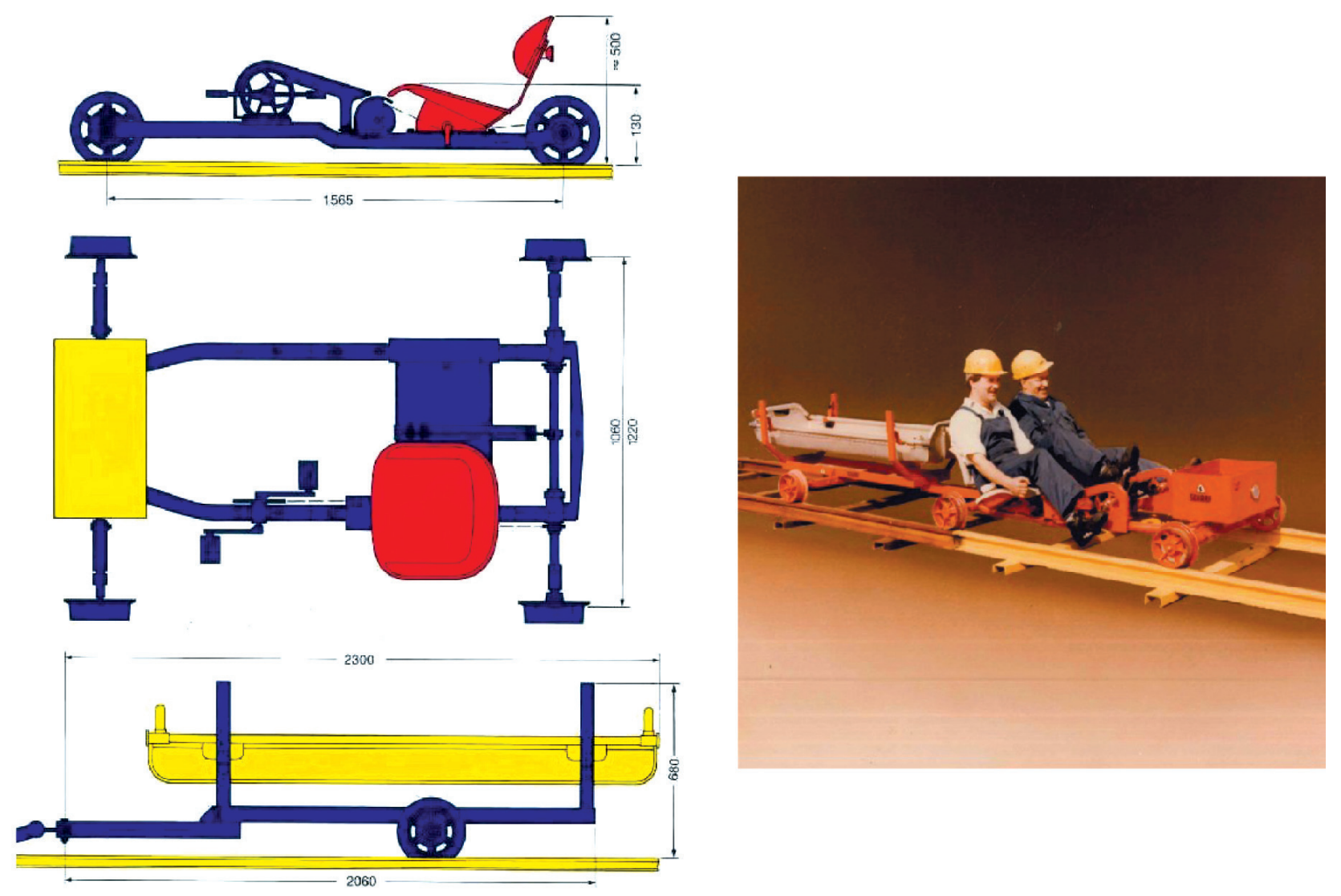

Fig. 9. Special model [6]

Table 3

Basic technical information about the Zg-Nr. S35011 bike (Fig. 9) [6]

\begin{tabular}{|l|c|}
\hline \multicolumn{1}{|c|}{ Model } & Zg-Nr. S35011 \\
\hline Total length $[\mathrm{mm}]$ & 1900 \\
\hline Height $[\mathrm{mm}]$ & 500 \\
\hline Curbweight $[\mathrm{kg}]$ & 90 \\
\hline Payload $[\mathrm{kg}]$ & 300 \\
\hline
\end{tabular}

The advantages of using miner's bikes were: fast transport between remote working with less tiredness of employees, extending effective worktime, cheap and easy transport of small loads, possibility of rapid evacuation of injured workers. There were also disadvantages, which made them disappear from underground mines, including: complicated construction, which made assembling (and disassembling) them long and difficult, the fact that passing them was almost impossible, high sensitivity to track conditions (which often happened to be bad in effect of bottom deformation), relatively high mass and failure to
Table 4

Basic information about the S-3501 trailer (Fig. 9) [6]

\begin{tabular}{|l|c|}
\hline \multicolumn{1}{|c|}{ Model } & Trailer S-3501 \\
\hline Total length [mm] & 2060 \\
\hline Height [mm] & 680 \\
\hline Curbweight $[\mathrm{kg}]$ & 42 \\
\hline Payload $[\mathrm{kg}]$ & 150 \\
\hline
\end{tabular}

comply with the law (construction made of aluminum, no lights). Moreover, the growing popularity of suspended rails (which made floor railway look old fashioned) also had an impact.

\section{AN IDEA FOR A NEW INDIVIDUAL MEANS OF TRANSPORT IN AN UNDERGROUND MINE USING A SUSPENDED RAIL TRACK (PATENT)}

Following an analysis of historical patents in light of modern technology, the idea of a new underground 
means of transport was born. The resulting brandnew miner's bike is a vehicle which connects the advantages of this historical individual means of transport with the utilization of a typical modern mine's equipment in accordance with legal regulations.

Suspended railways with friction wheel drives are clearly the most common means of transporting employees and materials in underground mines. They are usually equipped with a friction wheel drive, which works together with the rail. Pressure put on the rail by the drive wheel regulates the tractive force of the railway, in accordance with the track inclination or direction of transport.

In the Polish mining industry distances between main shafts and longwall headings are constantly growing. While this is not a problem in terms of staff and material transport, it can cause inconvenience in transferring small loads or single people behind scheduled time and route of monorails. Solving this problem is a real economic and practical issue.

This idea led to the construction of a vehicle for individual underground transport with its own drive, utilizing a monorail track while providing an appropriate level of mobility and safety. The projected construction of a new miner's bike consists of a carrier situated in the bottom part of a basic beam suspended on a rail. On the top part of the basic beam, the drive roller assembly is located. The drive rollers' rotation axes are horizontal and the drive wheel is connected to the drive which is located on the carrier. The essence of the solution is its mounting method on the rail. In the upper part of the basic beam there are horizontal stiff beams with other bars, vertically oriented, at their ends. Those bars are equipped with clamps with actual rollers.
Those rollers are mount on the lower part of the rail. Details of the construction are presented in the patent [13].

The greatest advantage of the proposed means of transport is that it can be mounted on, as well as dismantled from, a rail in default place of the track. The presented construction is designed to be used as a means of transport for staff (especially overlong distances), carriage for tools, small loads and devices or for maintaining the routes of the monorail, so its purpose is similar to that of the historical miner's bike. However, its simpler construction and lower mass makes it easier to use and more versatile. No previous training, permissions or licenses are needed. Another option to consider is whether to use an electric drive with a battery.

\subsection{Construction}

The main part of the bike's construction is a basic beam with a carrier, with a rider's seat on the beam's bottom and a drive roller assembly on its top. The drive assembly is installed on a bar which can be tilted in the horizontal plane of the basic beam. The drive wheel's axis is horizontal and the drive roller is connected with the hydrostatic transmission and drive in the front part of carriage. Two drive wheels are located symmetrically to the rail. Clamps used to stabilize the vehicle on the rail are wider than the rail, an advantage when it comes to mounting the bike on the track. Clamps are equipped with guiding wheels. Technical details are presented in patent [13]. Schemes of the new miner's bike are shown in Figures 10 and 11 .
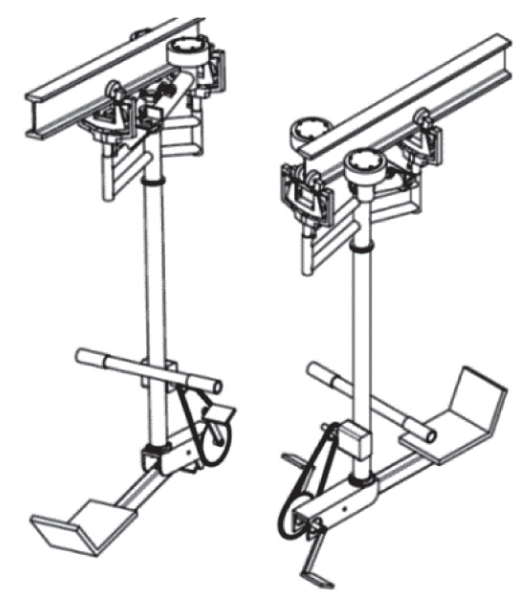

Fig. 10. Mean of individual underground transport with own drive 

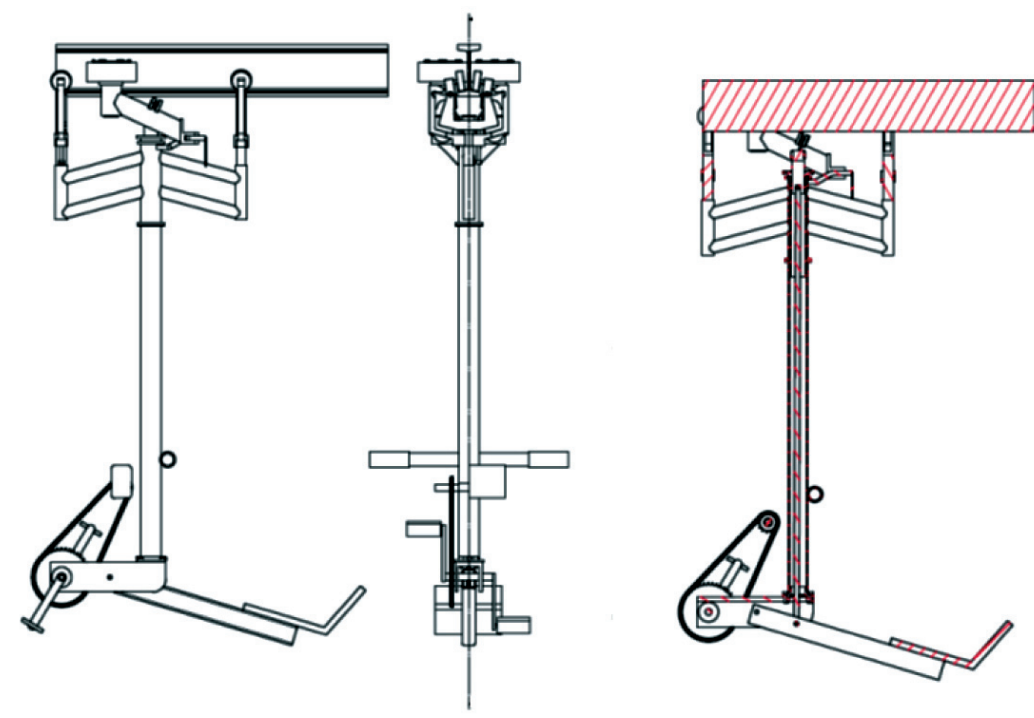

Fig. 11. Drive of the new miner's bike

\section{A PROTOTYPE OF THE MEANS OF TRANSPORT USING A SUSPENDED MONORAIL TRACK}

After analysis of the characteristics desired of means of individual underground transport, employees of the Shaft Sinking Company (PBSz S.A.) constructed a prototype and tested to check if the designed assumptions and solutions proposed in the patent had been met.

The prototype construction process was divided into two stages. The first consisted of a computer simulation, the other was a real-life underground test.

In the first phase, a virtual model of the bike was made which was then used in simulations with a "working model" software. The aim of the simulations was to specify the technical characteristics of the vehicle. The bike was tested to determine its maximum possible velocity, maximum inclination of ride and average pressure put on the pedals to set the bike in motion. The prototype model is presented in Figure 12 .

Observation of traditional bike's showed that pressure put on the pedals to make the bike move is greater than when the bike is already in motion. Based on this observation, a relationship was assigned between pressure on the pedals at the moment $t_{0}$ and its later reduction to $50 \%$ of its initial value (Fig. 13 and 14).

Several simulations of different bike versions were made in which different parameters were changed, such as track inclination, pressure on pedals, additional load on bike construction. The weight of the bike assessed in simulation was equal $40 \mathrm{~kg}$ and the mass of the bike's user was $80 \mathrm{~kg}$. Additionally, simulations included the use of the different type of wheels used: wheels made of steel and steel wheels covered with rubber. Example of the simulations are presented in the Figures 15 and 16.
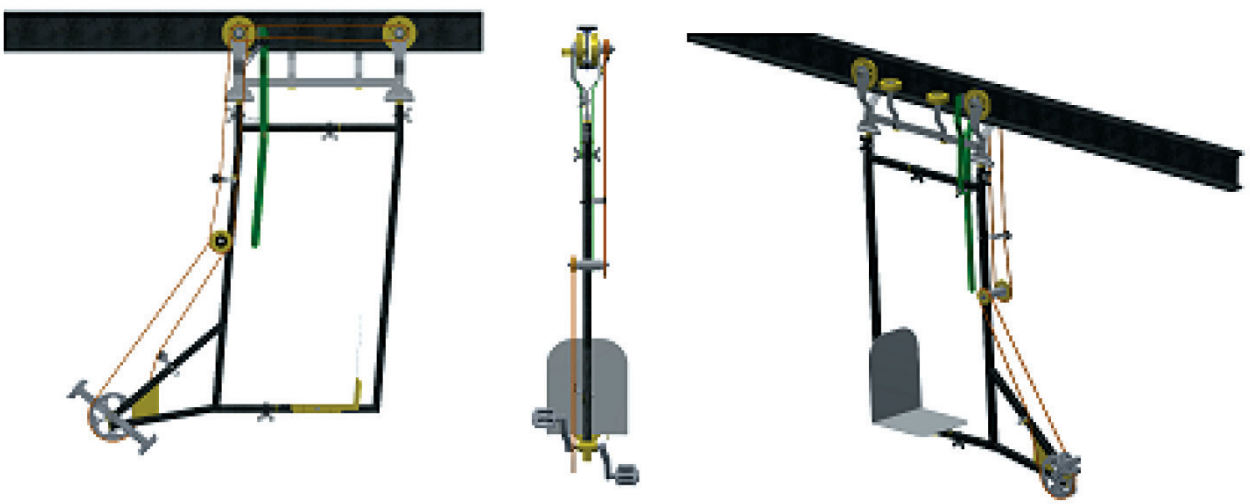

Fig. 12. Computer model of miner's bike 

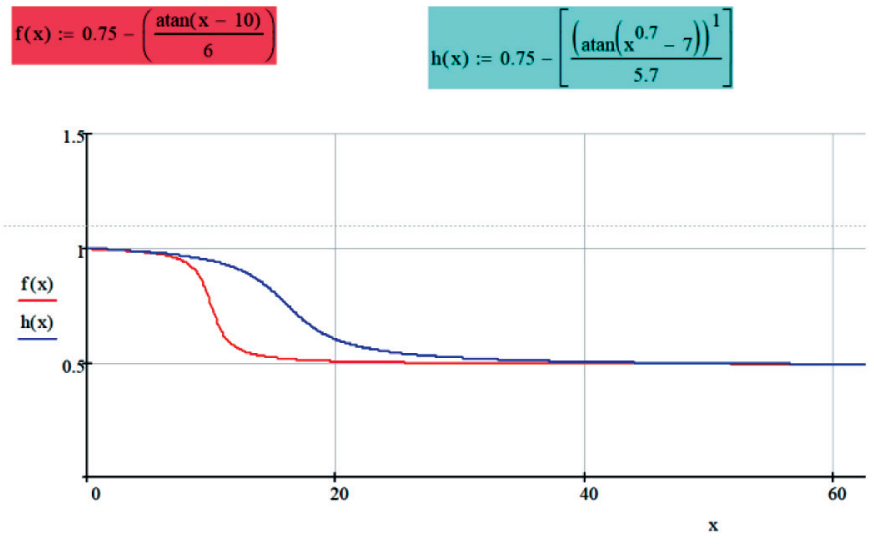

Fig. 13. Graph of relationship between load on pedals and time

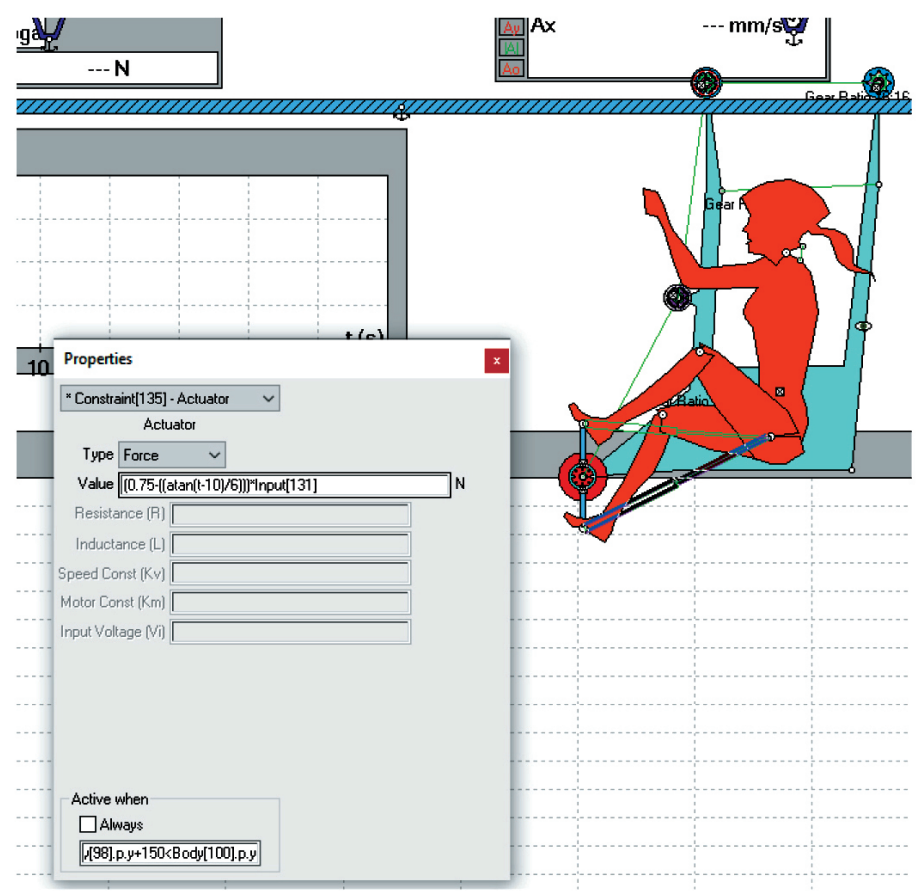

Fig. 14. Use of the function in Working Model programme

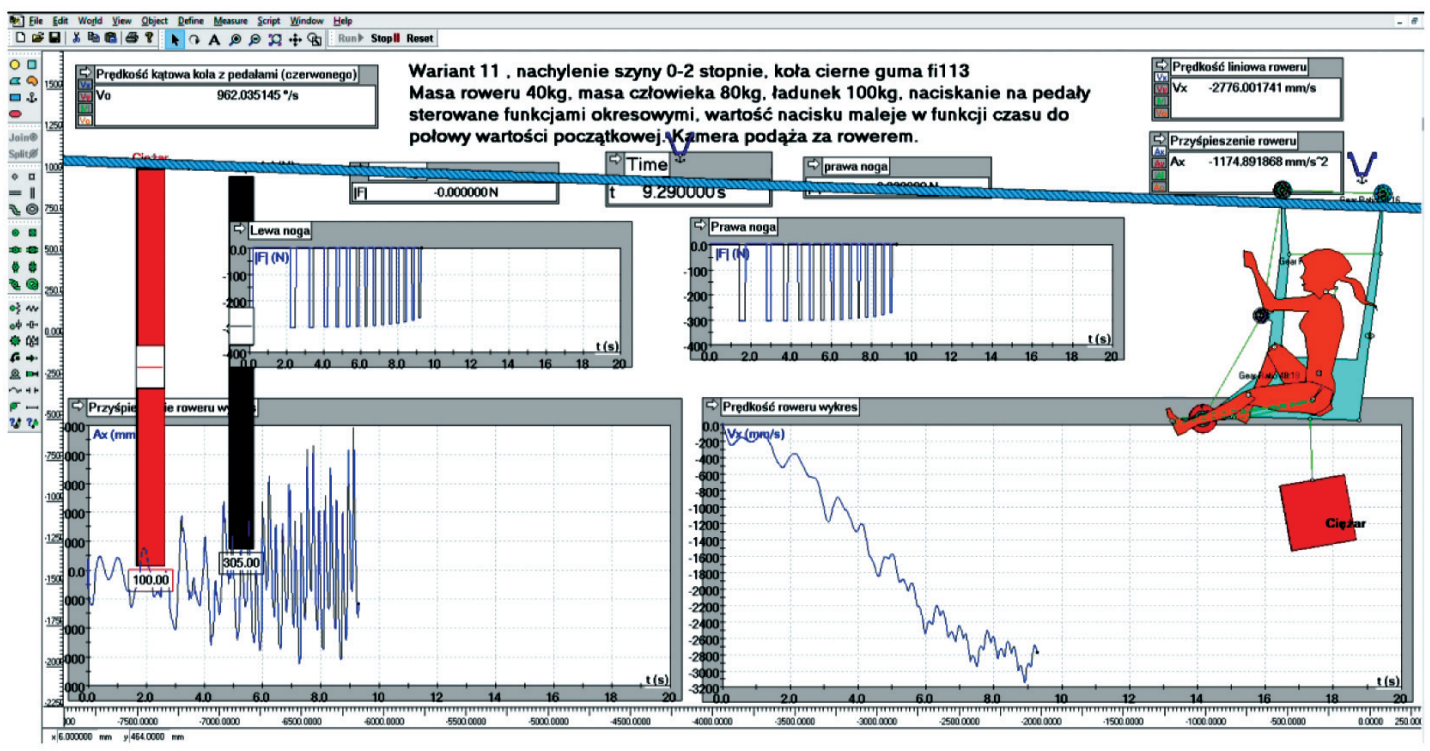

Fig. 15. Simulation of the bike with additional load 


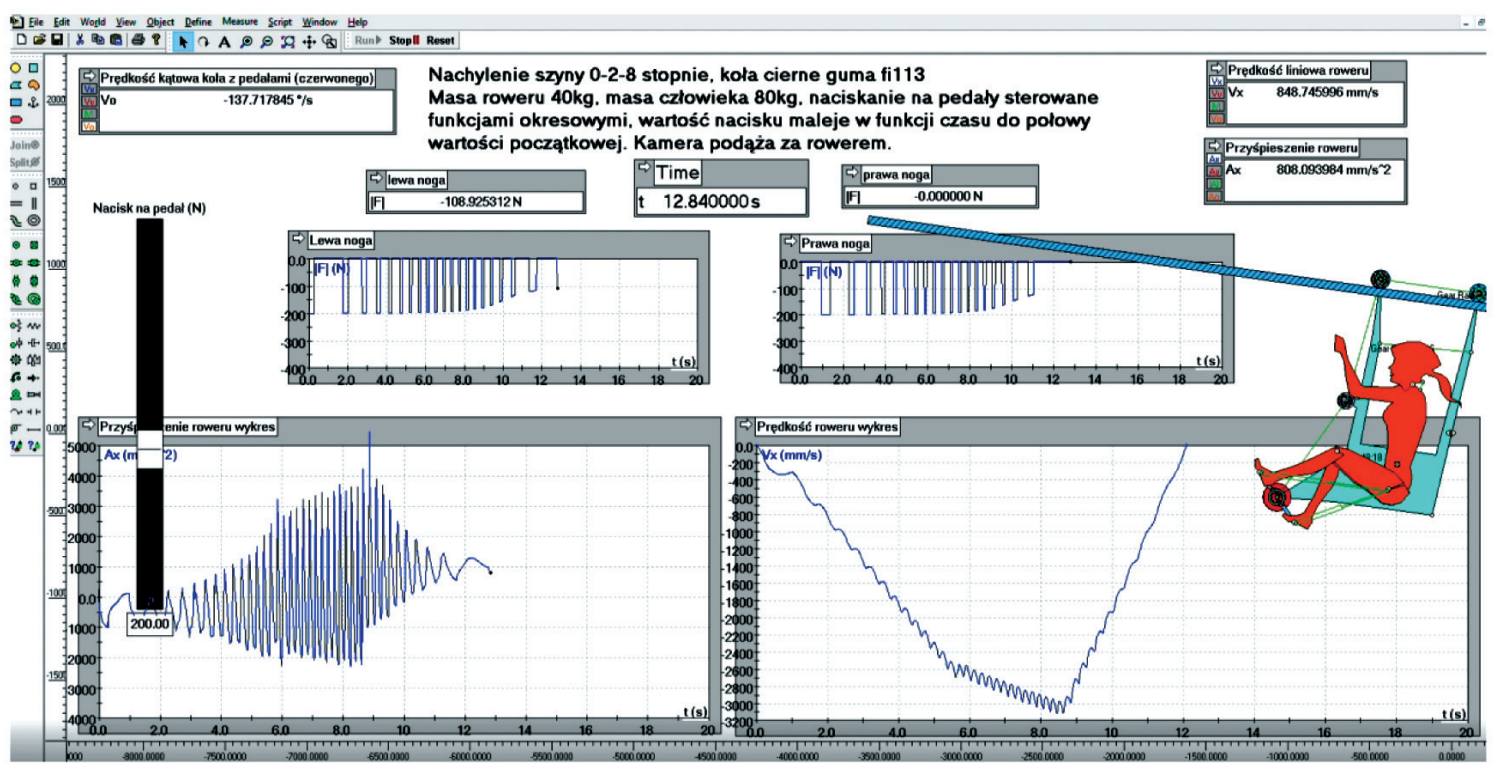

Fig. 16. Example of Working Model simulation

Simulations pointed out that rubber covered steel wheels work better because of the lower friction between rubber and steel rail than between wheels and rail that are both steel, meaning less force is needed to set the bike in motion. Maximum rail inclination for a bike equipped in steel wheels covered with rubber is equal to $10^{\circ}$.

The first real-life underground tests were conducted in Jastrzębie-Bzie ${ }^{1}$ colliery. Based on the observations, the following conclusions were made:

- The prototype weight $(36 \mathrm{~kg})$ is too high to mount the bike on the rail by one person (two are needed.

- The assembly of the bike can be done by one person only, but it is easier and faster when two persons work together. It is also convenient to use wingnuts instead of regular ones to make installation possible without tools.

- The stability of the bike is sufficient because of its low center of gravity. Pedaling does not cause the lateral movement of the vehicle.

- One-wheel drive is sufficient.

- Steel wheels tend to slide on the metal rail.

- Experiments were carried out for two different transmission ratios, with sprocket wheels $46 / 16$ and 22/16 teeth. The first configuration could require considerable effort to climb uphill, however the second one does not allow one to travel at the desired speed. It is recommended to use a sprocket wheel with an intermediate number of teeth -34 or 36 .

\footnotetext{
1 https://www.youtube.com/watch?v=2IniLx2nJU8
}

Photographs from underground tests are presented in Figure 17 and 18.

On the basis of another underground experiment carried out in the LW Bogdanka mine, similar conclusions were drawn. Additionally, it was suggested that side guiding wheels should be eliminated from the bike's construction.

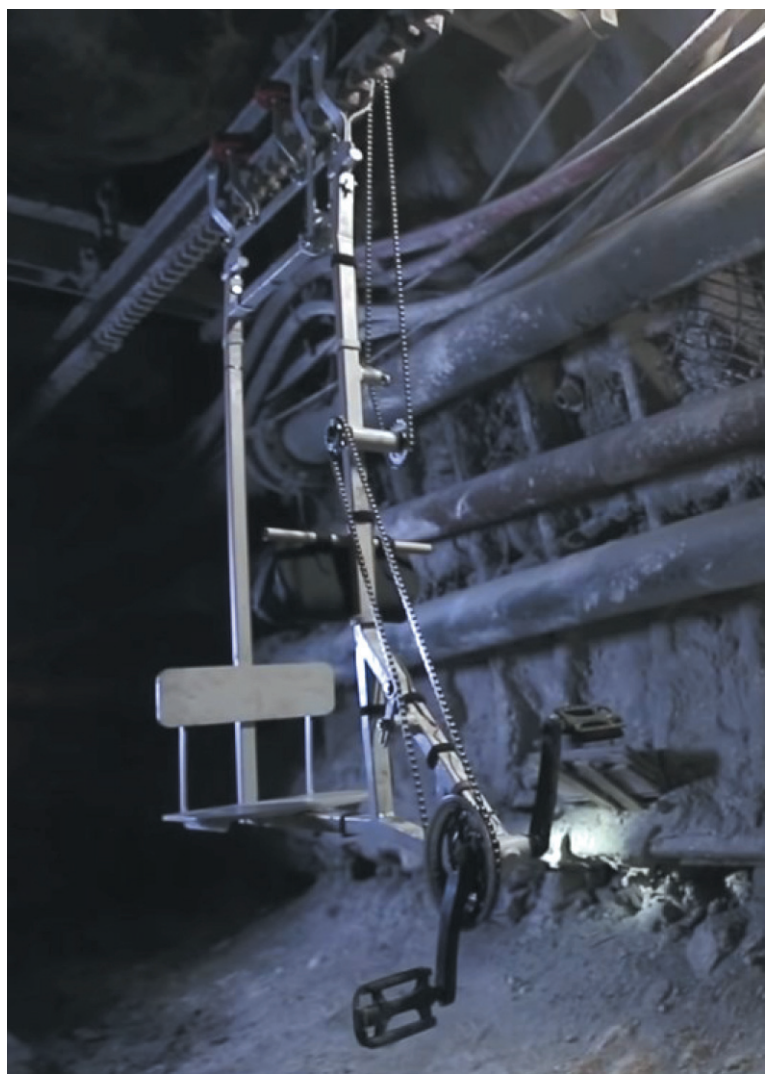

Fig. 17. New miner's bike prototype in an underground working 

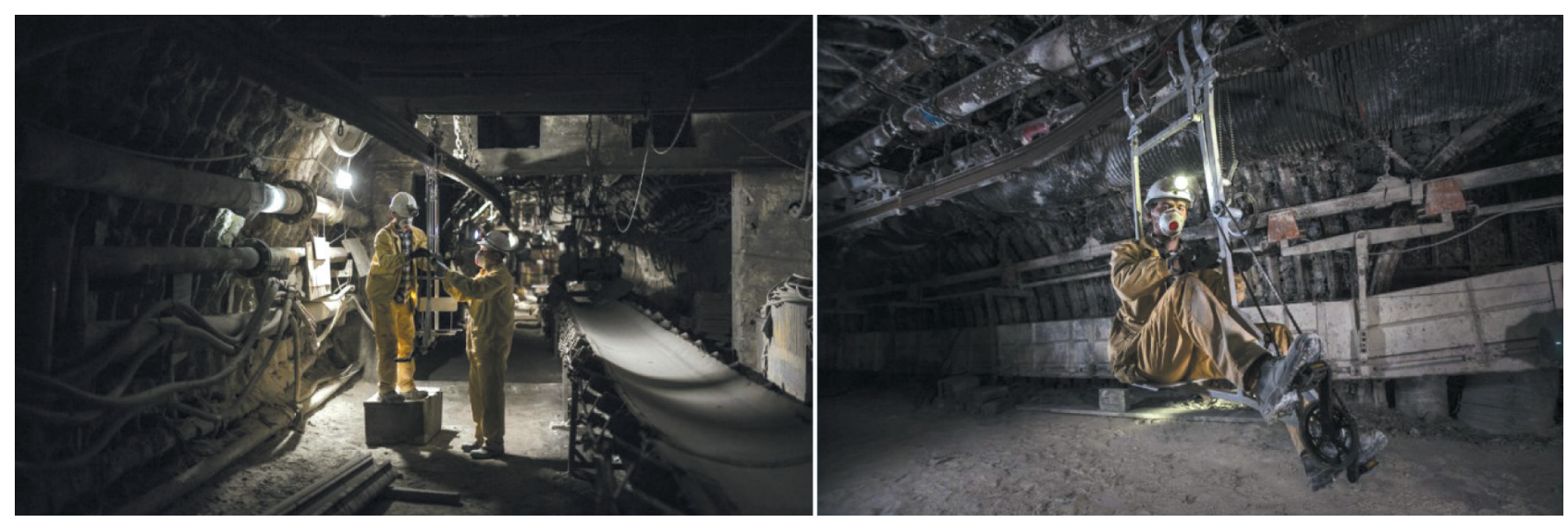

Fig. 18. Underground tests of a new miner's bike

\section{SUMMARY}

The presented vehicle is designed for mine workers whose work requires moving frequently between distant underground mine workings. The application of the bike could help reduce tiredness among staff and increase work efficiency by reducing time spent locomoting.

A bike prototype should be developed in accordance with legal requirements, as well as the demands of potential stakeholders and clients to make the final product safe and usable. The application of an electric or hydraulic drive should be considered.

\section{References}

[1] https://www.karldrais.de/?lang=en [20.04.2020].

[2] König, J.-G. Fahrradfahren. Von der Draisine bis zum E-Bike, Reclam Verlag, 2017.

[3] http://www.schwebebahn-wtal.de/tramenglish/indexgb.html [20.04.2020].

[4] Bianculli A.J.: Iron Rails in Garden State Tales of New Jersey Railroading, Indiana University Press 2008.

[5] US Patent Office Specification forming part of Letters Patent No. 488,201, December 20, 1892.

[6] SCHARF. Marketing materials - Grubendahrrader, Grubendahrrader 1955.

[7] http://www.geocities.ws/draisinenl/scharffolder.html [20.04.2020].

[8] Krischer R.: Alweg-Bahn: Technik, Geschichte und Zukunft der legendären Einschienenbahn, Transpress 2013.
[9] Richards B.: New Movement in Cities, Sterling Publishing Company 1966.

[10] Badura H., M. A. Rewolucja przemystowa w Europie, na ziemiach polskich i górnym ślasku, "Górnictwo - Perspektywy i Zagrożenia” 2016, 1(13): 314-322.

[11] Główny Instytut Górnictwa: Rowery kopalniane, "Nowości w Górnictwie" 1956, 13: 32.

[12] Volz, V. Mit Muskelkraft auf schaler Spur: Grubenfahrradaus Hamm, "Bahn-Express" 1994: 192-203.

[12] Heise-Herbst-Fritzche. Bergbaukunde; zweite band, Springer Verlag, Berlin - Heidelberg 1950.

[13] Patent PL P.418208 "Środek transportowy z własnym napędem do kolejki podwieszonej”.

KAZIMIERZ KUŹMA, M.Sc., Eng. KRZYSZTOF PYREK WOJCIECH KOCIK, M.Sc., Eng. PIOTR KALINOWSKI, M.Sc., Eng. Przedsiębiorstwo Budowy Szybów S.A. ul. Hutnicza 5-9, 42-600 Tarnowskie Góry, Poland \{kkuzma, kpyrek,wkocikpkalinowski\}@.jswpbsz.pl

PAWEŁ KAMIŃSKI, Ph.D., Eng. Przedsiębiorstwo Budowy Szybów S.A. ul. Hutnicza 5-9, 42-600 Tarnowskie Góry AGH University of Science and Technology al. Mickiewicza 30, 30-059 Krakow, Poland pkaminski@jswpbsz.pl,pkamin@agh.edu.pl 
KAZIMIERZ KUŹMA

KRZYSZTOF PYREK

WOJCIECH KOCIK

PIOTR KALINOWSKI

PAWEE KAMIŃSKI

\title{
Szynowy transport indywidualny oraz koncepcja środka transportu wykorzystującego tor kopalnianej kolei podwieszanej
}

\begin{abstract}
Drogi transportowe w polskich kopalniach węglowych stale się wydtuzaja. Nie stanowi to znacznego problemu w kontekście transportu materiałów i załogi, który powszechnie realizuje się z zastosowaniem kolejek podwieszanych z zespotami napędowymi ciernozębatymi. Utrudnienia pojawiają się w momencie konieczności transportu pojedynczych pracowników bądź niewielkich gabarytowo ładunków na znaczne odległości poza wyznaczonymi przewozami za pomoca kolejek podwieszanych.

Podjęte prace miały na celu opracowanie konstrukcji środka transportu indywidualnego z napędem wtasnym z zastosowaniem szyn kolejki podwieszanej, który będzie użytkowany poza zorganizowanym transportem zestawami kolejki podwieszanej, spetniajac wymagania odnośnie do jego mobilności i bezpieczeństwa.
\end{abstract}

Słowa kluczowe: rower podwieszany, indywidualny środek transportu

\section{WPROWADZENIE}

Rozważania na temat indywidualnego środka transportu, który mógłby znaleźć zastosowanie w istniejących podziemnych wyrobiskach kopalń zostaną poprzedzone omówieniem historii roweru i transportu szynowego.

12 czerwca 1817 r. w Mannheim Karl Drais zaprezentował rower biegowy (rys. 1), który w krótkim czasie zrewolucjonizował transport indywidualny. Wynalazek barona Draisa podlegał przez lata licznym modyfikacjom, dzięki którym powstał rower, jaki zna- my obecnie. W związku z popularnością, prostota i niezawodnością roweru jego zastosowanie zostało rozszerzone. W 1892 roku po przeprojektowaniu rower został przystosowany do jazdy po podwieszanych szynach i był wykorzystywany jako środek indywidualnego transportu miejskiego [1,2].

$\mathrm{Na}$ rysunku 2 przedstawiono zawieszany rower jednoszynowy na specjalnie wybudowanej linii łączącej Mount Holly i Smithville w New Jersey w Stanach Zjednoczonych. Został skonstruowany przez Arthura E. Hotchkissa i zbudowany w 1892 r.

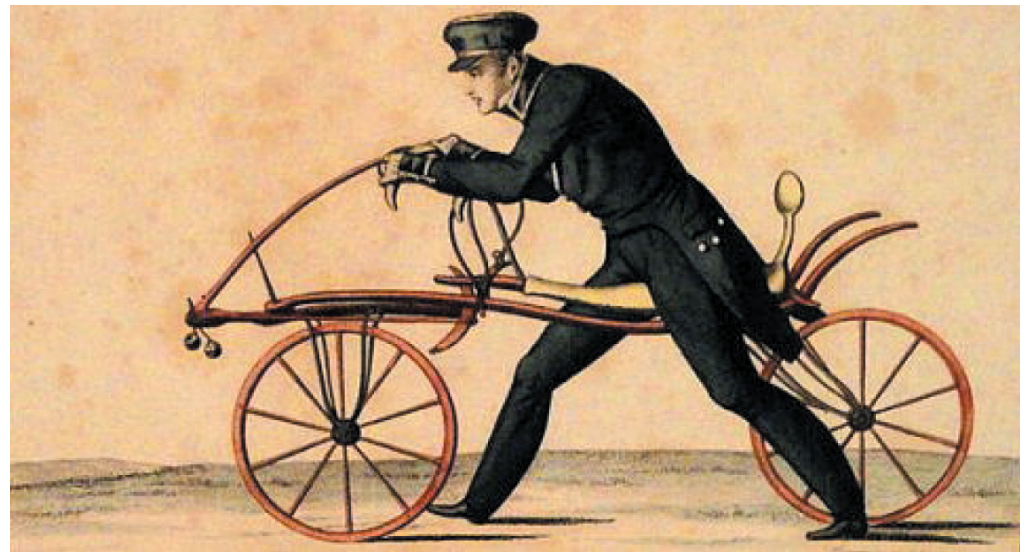

Rys. 1. Rower biegowy Karla Draisa [3] 


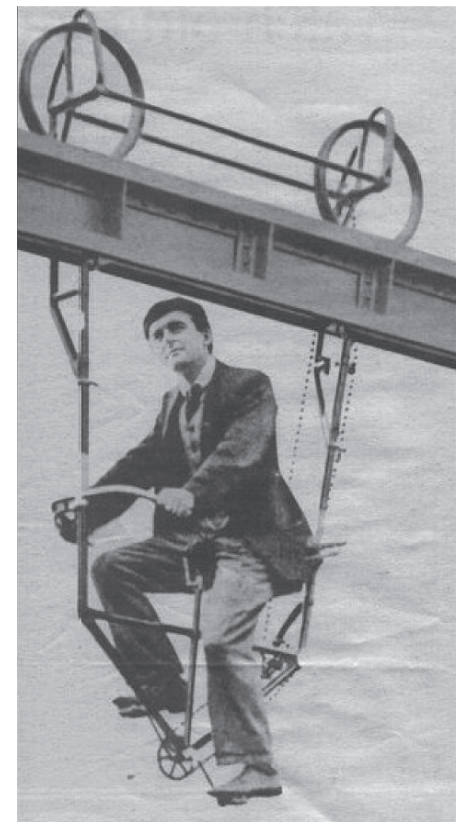

Rys. 2. Zawieszony rower jednoszynowy [4]

Specjalna linia rowerowa była przeznaczona głównie dla pracowników dojeżdżających do fabryk w Smithville. Osoby chcące odbyć podróż wypożyczały rower, który był dostępny w magazynach rozmieszczonych wzdłuż całej trasy. Głównymi wadami powyższego projektu był brak możliwości wyprzedzania oraz konieczność korzystania z jednej linii do jazdy w dwóch kierunkach, ponieważ druga linia nigdy nie została wybudowana, co przy dużym natężeniu ruchu w znaczny sposób spowalniało transport $[4,5]$.

\section{Transport jednoszynowy}

Jednoszynowe systemy transportu rozwinęły się stosunkowo niedawno, ich historia bowiem sięga początku XIX wieku. Obecnie dzieli się je na systemy wiszące (rys. 2) oraz systemy, w których środek transportowy znajduje się na szynie (rys. 3). Początek zastosowania transportu jednoszynowego przypada na 1820 r., kiedy to w miejscowości Miaczkowo (w dawnym Imperium Rosyjskim) wynalazca Iwan Elmanow zbudował podwyższoną jednotorową linię kolejową. Konie, poruszając się wzdłuż drewnianej szyny, ciągnęły po niej wózki. W związku z prostotą pomysł szybko zdobył popularność i znalazł zastosowanie w transporcie górników w krymskich kopalniach soli $[7,8]$.

Innym rosyjskim wynalazcą był książę Roman Biełozierski, który w 1836 r. zaproponował system jednoszynowy z dwoma rzędami kół, zbudowany na konstrukcji słupowej. W 1872 r. powstała kolej jednoszynowa Łuszczskiego, która została zaprezentowana podczas Wystawy Politechnicznej w Moskwie. Natomiast w 1874 r. rozpoczęto budowę jednoszynowej kolei Aleksieja Chludowa przeznaczonej do transportu drewna.

Kolej jednoszynowa prężnie rozwijała się nie tylko na terenie Rosji, ale także w innych częściach globu. Jednym z bardziej znanych pionierów tej technologii był angielski inżynier Henry Robinson Palmer, który w $1821 \mathrm{r}$. opatentował kolejkę jednoszynową (GB nr 4618). Linia została zbudowana na Deptford Quays w Londynie w 1824 r., zaś w czerwcu 1825 r. w Cheshunt uruchomiono kolej jednotorową przeznaczoną do transportu cegieł. Drewniane wagony zwisały pod relingiem i ciągnięte były przez konie. W Niemczech nad rozwojem transportu szynowego pracował Friedrich Harkort, który podjął próbę budowy trasy demonstracyjnej między miastami Elberfeld i Barmen, obecnie dzielnicami miasta Wuppertal. W 1827 r. udoskonalił kolej Palmera - zamiast koni pociągowych wykorzystał silniki parowe. W kolejnych latach koleje jednoliniowe były udoskonalane, czego rezultatem jest współczesna Wuppertaler Schwebebahn, najdłuższa na świecie linia kolei podwieszanej, obecnie łącząca dzielnice Oberbarmen (Barmen) i Vohwinkel (rys. 4) [3].

W procesie rozwoju kolei jednoszynowych wykształcił się podział na systemy z napędem zewnętrznym oraz napędem własnym. Historycznym przykładem kolei jednoszynowej $\mathrm{z}$ napędem własnym jest Bicycle Railroad (rys. 5), stworzona przez Arthura Ethelberga Hotchkissa z New Haven w Nowej Anglii, opatentowana w grudniu 1892 r. (US 488.201) [5].

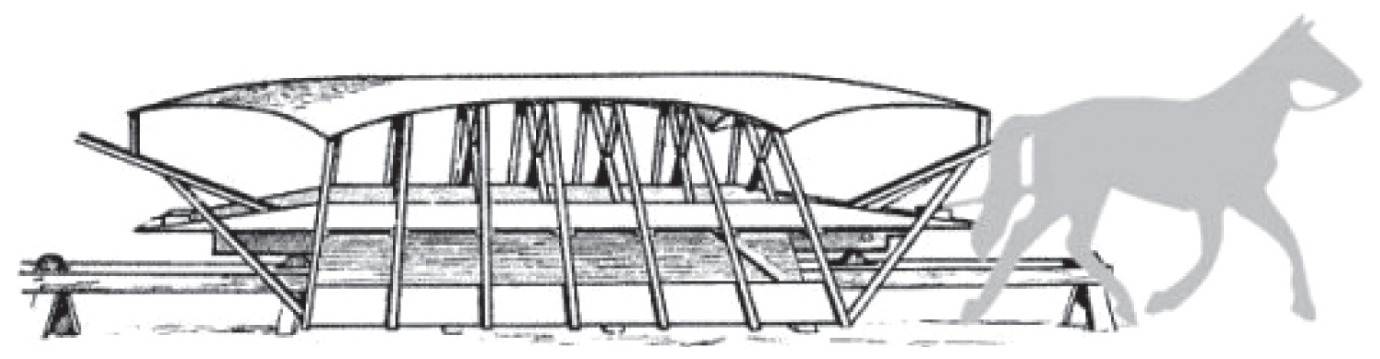

Rys. 3. Transport szynowy Iwana Elmanowa [8] 


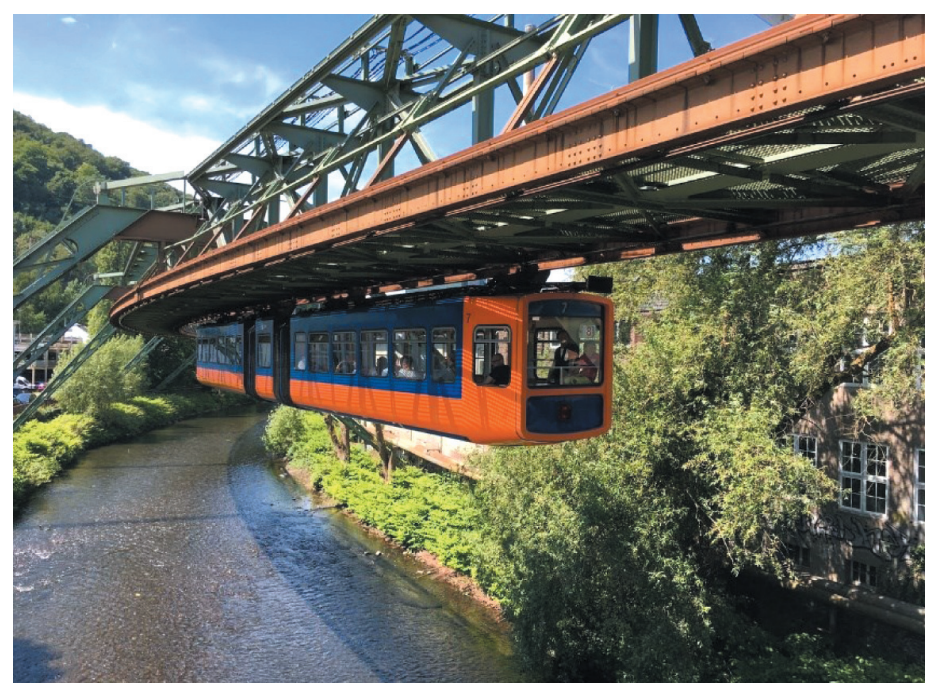

Rys. 4. Kolej Wuppertaler Schwebebahn [3]
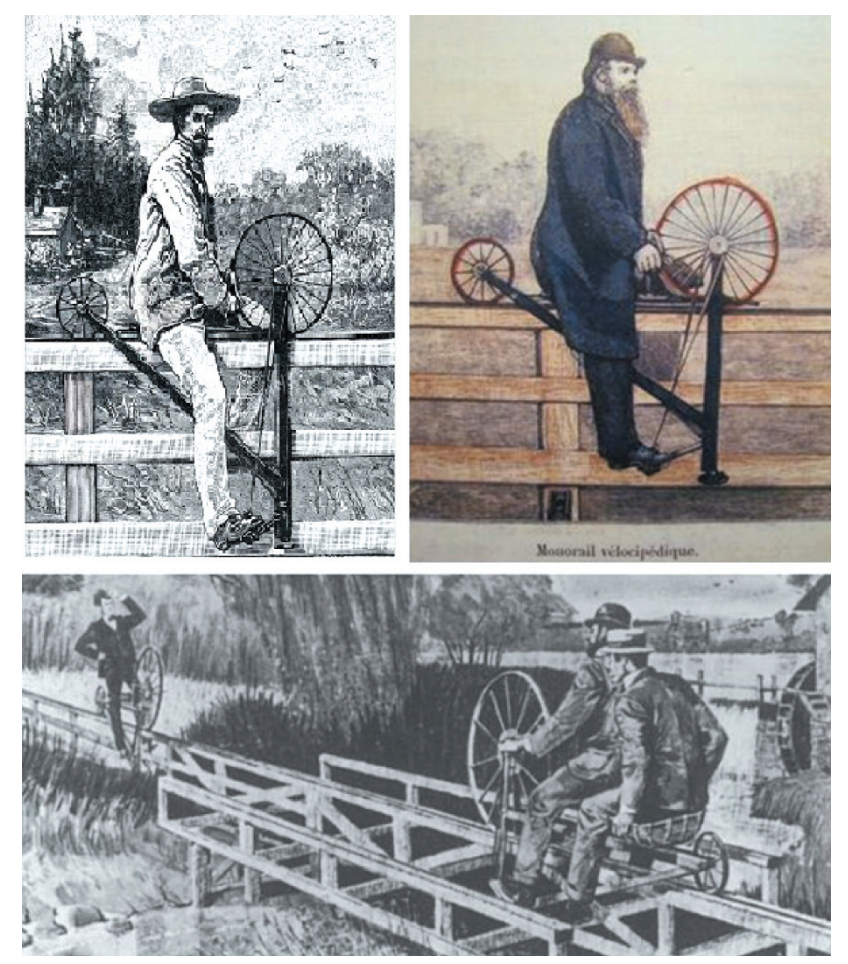

Rys. 5. Bicycle Railroad [4]

\subsection{Historyczne zastosowanie rowerów jako indywidualnego środka transportu w górnictwie podziemnym}

Dynamiczny rozwój przemysłu na przełomie XIX i XX w. spowodował znaczny wzrost zapotrzebowania na węgiel, który był wówczas podstawowym surowcem energetycznym. Rosnace wydobycie wymuszało ciągłą rozbudowę kopalń. Wraz z rozwojem przestrzennym zakładów górniczych zwiększały się odległości między szybem a miejscem wykonywania pracy, czego efektem był intensywny rozwój improwizowanych środków transportu. Kopalnie chętnie adapto- wały rozwiązania stosowane na powierzchni do warunków panujących w podziemnych wyrobiskach. Ówczesna popularność roweru w przestrzeni miejskiej sprawiła, że ten środek transportu, w zmodyfikowanej formie, stał się powszechny w zakładach górniczych, szczególnie w Niemczech i Holandii. Początkowo górnicze rowery były wytwarzane w kopalniach, w niewielkich ilościach, ponieważ produkt nie był dostępny na rynku. W 1954 r. firma Scharf GmbH z Hamm zaprezentowała i wprowadziła do sprzedaży pierwszy seryjny rower górniczy - Grubenflitzer. Logo oraz broszurę prezentującą pierwszy rower górniczy przedstawiono na rysunku 6 [9-11]. 

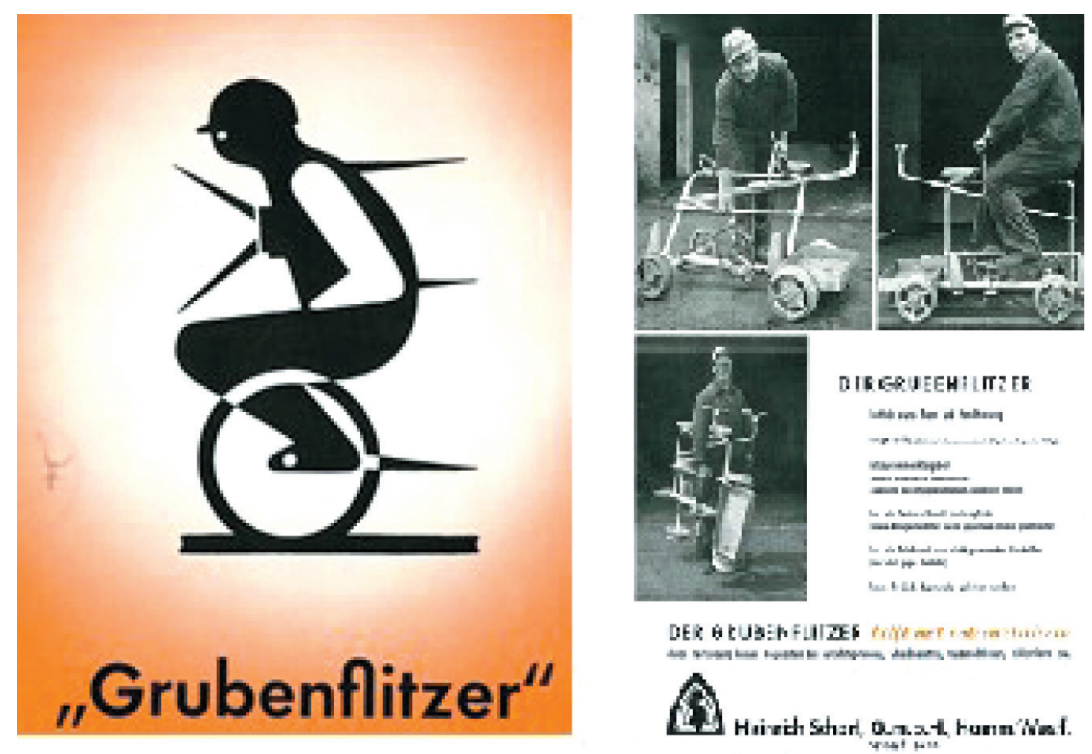

Rys. 6. Logo i materiały reklamowe pierwszego roweru górniczego produkowanego na skalę masowa [11]

Grubenflitzer był przeznaczony głównie dla osób, których praca wiązała się z koniecznością częstego przemieszczania się w podziemnych wyrobiskach kopalń. Do tej grupy należeli przede wszystkim pracownicy dozoru ruchu, cieśle, elektrycy itp. Prototyp był dość prostą, niską konstrukcją z bagażnikiem przymocowanym z tyłu. Pojazd wzbudził nawet zainteresowanie ówczesnego federalnego ministra gospodarki, a późniejszego kanclerza RFN Ludwiga Erharda na wystawie górniczej w Essen w 1954 r. W kolejnych latach sprzedaż pojazdu wynosiła 30-40 sztuk miesięcznie. Grubenflitzer był modernizowany, m.in. zaczęto wykonywać rowery w różnych wariantach dostosowanych do wysokości wyrobiska, pojazdy wyposażano w skrzynki narzędziowe oraz zastosowano stop AlMgSi, który jest odporny na koro- zję, a także pozwolił na zmniejszenie pierwotnej wagi roweru do $30 \mathrm{~kg}$.

W zależności od przeznaczenia roweru, odległości, na jakie miał się poruszać, jego dopuszczalnej ładowności, a także parametrów wyrobisk, przedsiębiorstwo wykonało kilka typów rowerów górniczych, które przedstawiono poniżej.

Podstawowym modelem produkowanym przez Scharf GmbH był rower kopalniany Zg-Nr. 35003-00.00 (rys. 7) ze składaną ramą wykonaną $\mathrm{z}$ aluminium. Pojazd był oferowany $w$ wariantach $z$ dwoma siodełkami i jedną skrzynką narzędziową, jednym siodełkiem i jedną skrzynką lub jednym siodełkiem z dwoma skrzynkami narzędziowymi, natomiast rower S-35017 był wyposażony w dwie skrzynki i dwa siodełka. Podstawowe dane techniczne zostały przedstawione $\mathrm{w}$ tabeli $1 \mathrm{i}$ na rysunku 7 [6].
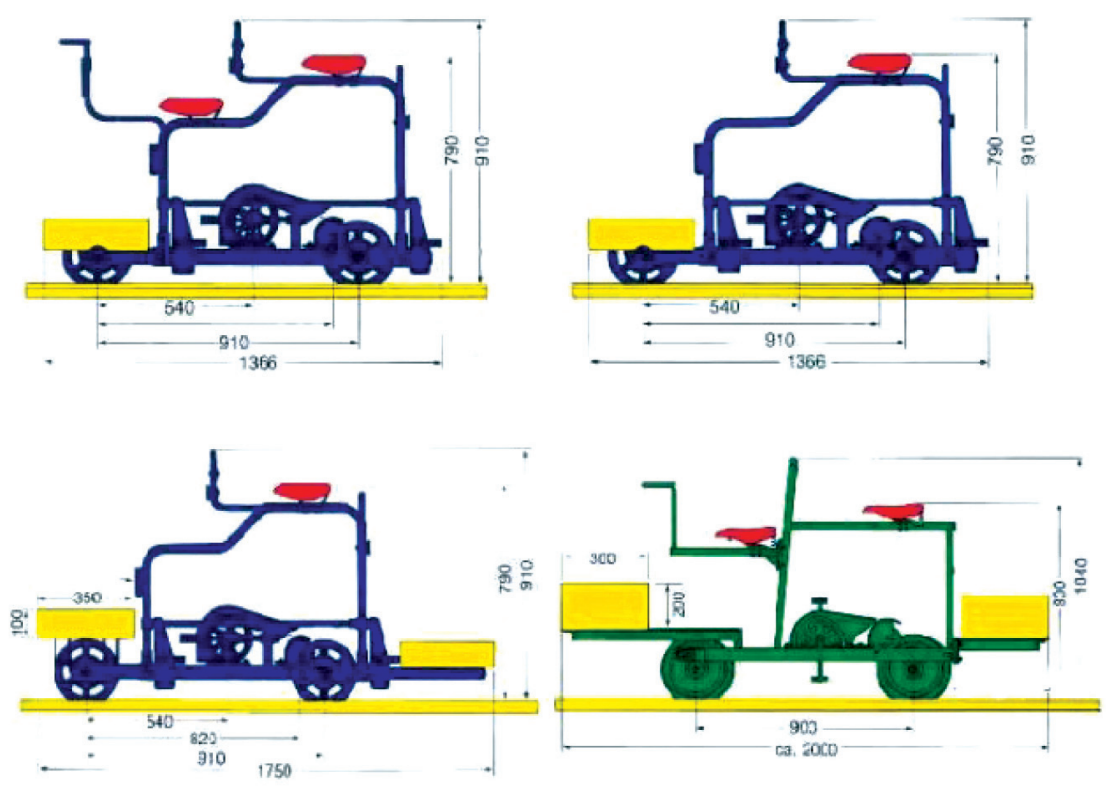

Rys. 7. Model podstawowy roweru górniczego w różnych wariantach [6] 
Tabela 1

Podstawowe dane techniczne modeli

Zg-Nr. 35005-00.00 i Zg-Nr. S-35017 (rys. 7) [6]

\begin{tabular}{|l|c|c|}
\hline \multicolumn{1}{|c|}{ Model } & Zg-Nr. 35003-00.00 & Zg.-Nr. S-35017 \\
\hline Długość całkowita [mm] & 1366 & 2000 \\
\hline Wysokość [mm] & 910 & 1040 \\
\hline Masa własna [kg] & 50 & 100 \\
\hline Ladowność $[\mathrm{kg}]$ & 200 & 250 \\
\hline
\end{tabular}

Następny model miał skrzynkę $\mathrm{z}$ wyposażeniem z przodu i wózek z trzypunktowymi łożyskami, aby uniknąć wykolejenia nawet przy złych warunkach torowiska. W ciasnych przestrzeniach rower można było złożyć w prosty sposób. Ponadto do wytwarzania niektórych części zastosowano odporny na korozję
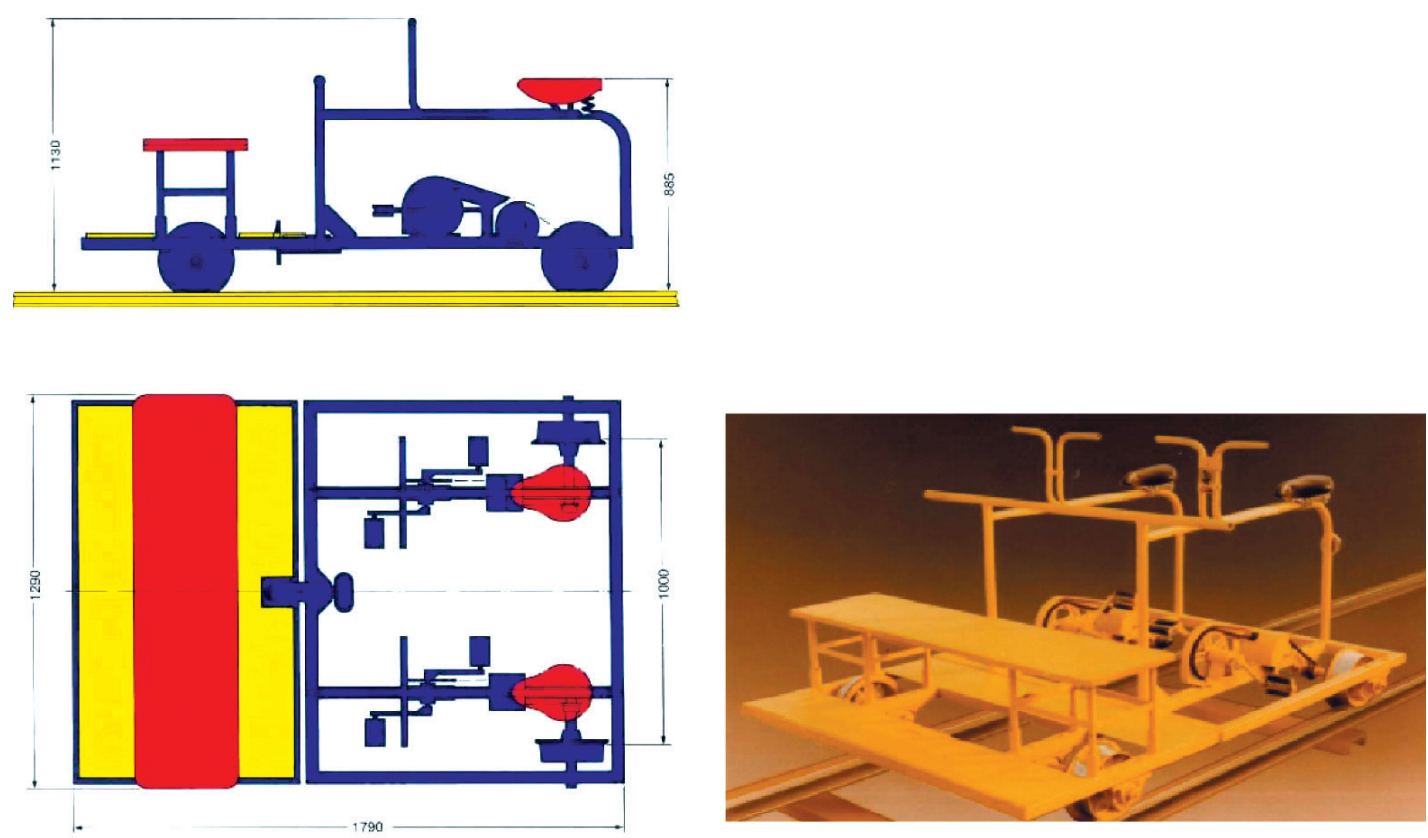

Rys. 8. Pięcioosobowy rower ratowniczy Zg-Nr. S-135016 [6]

Pojazd został zbudowany z myślą o zastosowaniu na krótkich odległościach. Był wyposażony w dwa umieszczone obok siebie fotele kubełkowe, dwa napędy i skrzynkę narzędziową zamontowaną z przodu. Najwyższym punktem roweru była górna krawędź fotela kubełkowego. Do roweru można było doczepić przyczepę o wysokości $680 \mathrm{~mm}$ i masie $42 \mathrm{~kg}$. Podstawowe dane techniczne roweru oraz przyczepy przedstawiono na rysunku 9 oraz w tabelach 3 i 4.

Nie podlega wątpliwości, że w czasach niskiej mechanizacji górnictwa rowery górnicze przyczyniły się do rozwoju przemysłu wydobywczego. Pozwoliły wydatnie skrócić nieefektywny czas pracy wynikający stop 6060 (EN AW-AlMgSi), co skutkowało zmniejszeniem masy pojazdu.

Model Zg-Nr. S-135016 został zaprojektowany jako pojazd ratowniczy. Był wyposażony w dwa napędy, hamulec nożny oraz ławkę, na której mogły siedzieć trzy osoby. Podstawowe dane roweru zostały przedstawione w tabeli 2 i na rysunku $8[6,12]$.

Tabela 2

Podstawowe dane techniczne pięcioosobowego roweru ratowniczego Zg-Nr. S-135016 (rys. 8) [6]

\begin{tabular}{|l|c|}
\hline \multicolumn{1}{|c|}{ Model } & Zg-Nr. S-135016 \\
\hline Długość całkowita $[\mathrm{mm}]$ & 1790 \\
\hline Wysokość $[\mathrm{mm}]$ & 130 \\
\hline Masa własna $[\mathrm{kg}]$ & 130 \\
\hline Ladowność $[\mathrm{kg}]$ & 600 \\
\hline
\end{tabular}




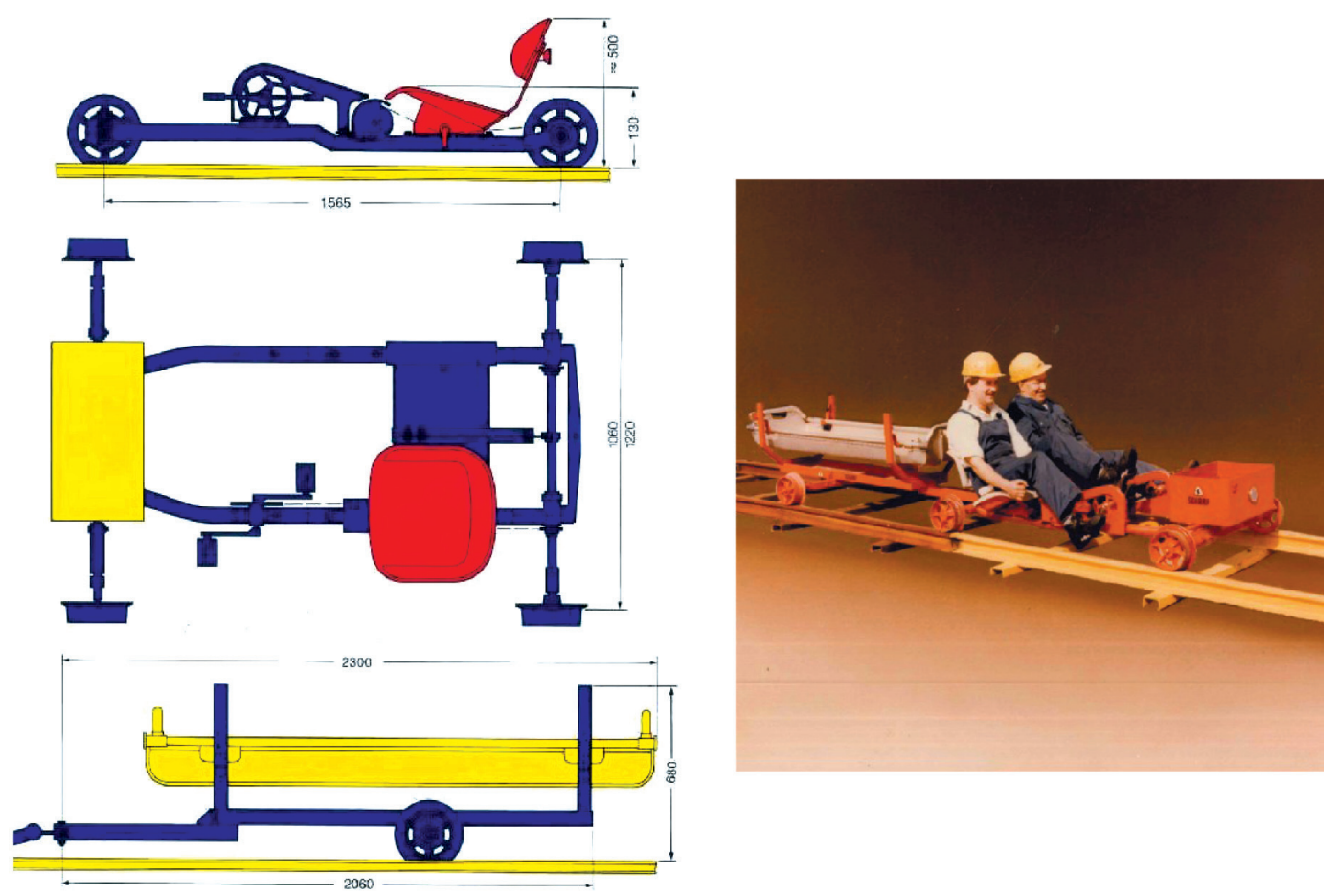

Rys. 9. Model specjalny [6]

Tabela 3

Podstawowe dane techniczne roweru Zg-Nr. S35011 (rys. 9) [6]

\begin{tabular}{|l|c|}
\hline \multicolumn{1}{|c|}{ Model } & Zg-Nr. S35011 \\
\hline Długość całkowita $[\mathrm{mm}]$ & 1900 \\
\hline Wysokość $[\mathrm{mm}]$ & 500 \\
\hline Masa własna $[\mathrm{kg}]$ & 90 \\
\hline Ladowność $[\mathrm{kg}]$ & 300 \\
\hline
\end{tabular}

Pośród zalet przedstawionych rowerów kopalnianych należy wymienić możliwość szybkiego transportu osób oraz niewielkich ładunków na znaczne odległości w stosunkowo krótkim czasie, co wpływało na zwiększenie efektywności pracy oraz minimalizację zmęczenia pracownika wynikającego z konieczności pieszego przemieszczania się, a także możliwość błyskawicznej ewakuacji pracownika, który uległ wypadkowi. Wadami, które doprowadziły ostatecznie do zaniechania stosowania rowerów, były natomiast: konstrukcja uniemożliwiająca szybki montaż i demontaż urządzenia, co sprawiało, że wymijanie było skomplikowaną operacją, duży wpływ deformacji spągu na stan torów oraz kolizyjność rozwiązań konstrukcyjnych z przepisami prawa górniczego (aluminiowa konstrukcja, brak oświetlenia). Dodatkowym czynnikiem, który przyczynił się do usunięcia rowerów z podziemnych wyrobisk, był wzrost popularności kolejek podwieszanych i zastępowanie przez nie kolejek spągowych.
Tabela 4

Podstawowe dane techniczne przyczepy S-3501 (rys. 9) [6]

\begin{tabular}{|l|c|}
\hline \multicolumn{1}{|c|}{ Model } & Przyczepa S-3501 \\
\hline Długość całkowita [mm] & 2060 \\
\hline Wysokość [mm] & 680 \\
\hline Masa własna [kg] & 42 \\
\hline Ladowność $[\mathrm{kg}]$ & 150 \\
\hline
\end{tabular}

\section{KONCEPCJA NOWEGO INDYWIDUALNEGO ŚRODKA TRANSPORTU ${ }^{1}$ WYKORZYSTUJACCEGO TOR KOPALNIANEJ KOLEI PODWIESZANEJ (PATENT)}

Obserwując historyczne wynalazki oraz wykorzystując aktualną technologię, opracowano koncepcję nowego środka transportu kopalnianego. Nowy „,rower kopalniany" jest urządzeniem mającym zalety indywidualnych środków transportu stosowanych w przeszłości, przystosowanym do aktualnych rygorów bezpieczeństwa oraz wykorzystującym powszechnie stosowane wyposażenie poziomych wyrobisk kopalń podziemnych.

Aktualnie do transportu materiałów oraz załogi w górniczych wyrobiskach podziemnych często stosowane są kolejki podwieszane. Do napędu po szynie

\footnotetext{
${ }^{1}$ Dalej IŚT.
} 
torowiska kolei podwieszanej wykorzystywane są zespoły napędowe cierno-zębate. Takie napędy ciągników kolejek wyposażone są w poziome napędowe koła cierne, współpracujące ze środnikiem szyn torowiska i zawieszone są kołami jezdnymi na stopce szyny torowiska - docisk poziomych kół napędowych do środnika szyn torowiska umożliwia zróżnicowanie regulowanej siły pociągowej pojazdu podwieszanego w zależności od nachylenia trasy czy też kierunku transportu, a więc pchania lub ciągnienia zestawów.

W górnictwie polskim daje się zauważyć tendencję do stałego wydłużania się dróg transportowych pomiędzy wyrobiskami eksploatacyjnymi a szybami. Nie stwarza to znacznego problemu w odniesieniu do transportu towarów masowych oraz znacznej liczebnie załogi na zwiększające się odległości, jednakże powstaje problem transportu niewielkich gabarytowo ładunków, czy też pojedynczych osób, na znaczne odległości poza normalnymi przewozami pociągowymi za pomocą kolejek podwieszanych. Rozwiązanie tego problemu ma istotne znaczenie praktyczne i ekonomiczne.

Celem koncepcji było opracowanie konstrukcji takiego środka transportowego $\mathrm{z}$ własnym napędem dla kolejki podwieszanej, który będzie mógł być użyty poza zorganizowanym transportem zestawami kolejki podwieszanej, a przy tym będzie mobilny i bezpieczny. Proponowany środek transportowy $z$ własnym napędem do kolejki podwieszanej charakteryzuje się tym, że platforma nośna osadzona jest na dolnym końcu belki nośnej zawieszonej na szynie torowiska, przy czym belka nośna wyposażona jest na górnym końcu w zespół przemieszczających rolek jezdnych o zasadniczo poziomych osiach obrotu, oraz posiada co najmniej jedno dociskane do środnika szyny, z możliwością odchylania, koło napędowe połączone $\mathrm{z}$ napędem umieszczonym na platformie nośnej. Istota rozwiązania polega na tym, że w części górnej pionowa belka nośna ma wzdłużne, sztywne łączniki zakończone pionowymi wspornikami wyposażonymi w otwarte od góry obejmy, w których zamocowane są wahliwie, w płaszczyźnie prostopadłej do szyny torowiska, pary rolek jezdnych posadowionych na dolnych półkach szyny.

Proponowany środek transportu może być zawieszony na szynie trasy kolejki podwieszanej w każdym miejscu trasy, a także w dowolnym miejscu zdjęty $\mathrm{z}$ torowiska. Przedstawiony rower może być użyty jako wózek osobowy, służący do przemieszczania członków załogi górniczej na znaczne odległości, bez wykorzystania zestawu kolejki podwieszanej, czy też jako wózek do przemieszczania narzędzi lub sprzętu, co spowoduje ograniczenie pracy ręcznej, względnie jako wózek do porządkowania dróg transportowych. W swoich założeniach jest zbliżony do historycznych rowerów górniczych, jednak jego konstrukcja i zasto- sowanie są prostsze. Jako urządzenie lekkie może być przez jedną osobę osadzany na torowisku i zdejmowany z szyn torowiska $\mathrm{w}$ dowolnie wybranym miejscu, nie wymaga także zdobywania żadnych uprawnień bądź odbywania dodatkowych szkoleń. Zamiast napędu nożnego może być wykorzystany napęd elektryczny z zastosowaniem akumulatorów [13].

\subsection{Budowa}

Wewnątrz pionowej belki nośnej osadzone jest przesuwnie suwadło połączone jednym dolnym końcem z platformą nośną z siedziskiem, a drugim, wystającym z belki nośnej, górnym końcem połączone przegubowo z przynajmniej jednym, zamocowanym wahliwie w płaszczyźnie poziomej do tejże belki, ramieniem wyposażonym w element napędowy koła napędowego o pionowej osi obrotu. Element napędowy łączy się z przekładnią hydrostatyczną połączoną z układem zasilającym zamocowanym na belce poziomej w przedniej części platformy nośnej. Dobrym rozwiązaniem jest, że każda obejma osadzona na pionowym wsporniku ma prześwit większy od szerokości dolnych półek szyny torowiska, zaś na końcach ramion ma osadzone wahliwie, w płaszczyźnie prostopadłej do szyny, wodziki z zamocowanymi obrotowo na ich górnych końcach rolkami jezdnymi. Jednocześnie na obejmę zachodzi od dołu osadzona przesuwnie na wsporniku klamra ryglująca, zakończona poziomymi występami usytuowanymi poniżej wodzików (rys. 10).

Korzystne jest, gdy każdy z wodzików ma trzonek zamocowany obrotowo na osi umieszczonej w otworze usytuowanym w ramieniu obejmy oraz ma kształtowe odsadzenie. W górnej części każdego trzonka zamocowana jest obrotowo rolka jezdna o osi obrotu prostopadłej do osi umieszczonej w otworze, a dolna część trzonka jest w ślizgowym styku z krawędzią dolnej półki szyny. Wyprofilowaną górną krawędzią opiera się o poziomy występ klamry ryglującej, a zewnętrzne ścianki obejmy są zbieżne ku jej otwarciu, przy czym szerokość obejmy jest większa niż odległość między końcami poziomych występów klamry ryglującej. Obejma zawiera rygiel klamry ryglującej. Koło napędowe osadzone jest w elemencie napędowym zamocowanym do ramienia, które wyposażone jest w uchwyt połączony sztywnym ciągadłem z górnym końcem suwadła osadzonego wewnątrz pionowej belki nośnej. Dobrym rozwiązaniem jest zastosowanie dwóch kół napędowych usytuowanych symetrycznie względem środnika szyny oraz konstrukcja siedziska platformy nośnej w postaci wahliwej belki (rys. 11). Szczegóły techniczne zostały szczegółowo przedstawione $\mathrm{w}$ opisie patentowym [13]. 

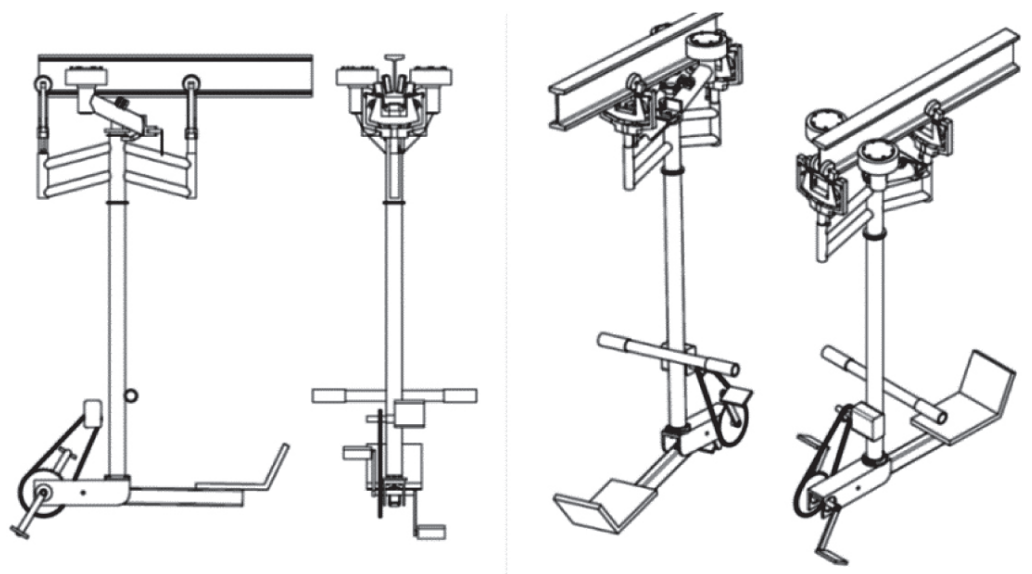

Rys. 10. IŚT z napędem własnym
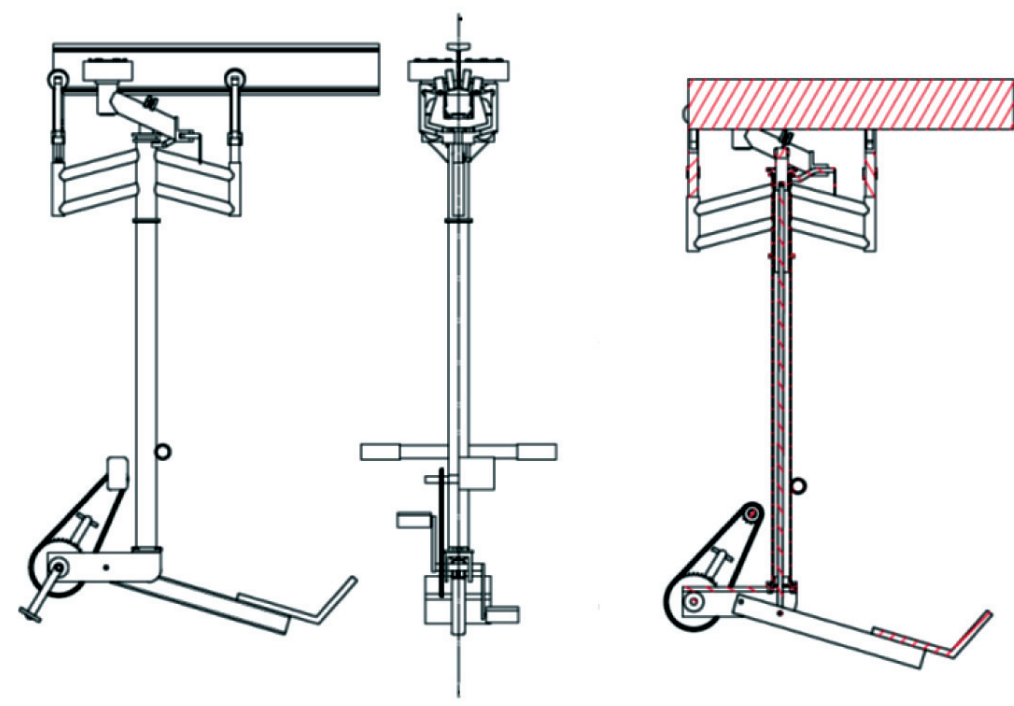

Rys. 11. Napęd IŚT

\section{PROTOTYP ŚRODKA TRANSPORTU WYKORZYSTUJACEGO TOR KOPALNIANEJ KOLEI PODWIESZANEJ}

Analizując cechy, jakie powinien mieć indywidualny środek transportu, pracownicy Przedsiębiorstwa Budowy Szybów S.A. wykonali jego prototyp w celu sprawdzenia poprawności założeń i propozycji rozwiązań przedstawionych w opisie patentowym (punkt trzeci).

Budowa prototypu odbyła się w dwóch etapach: przeprowadzenie symulacji komputerowych i przeprowadzenie prób dołowych.

W pierwszym kroku został wykonany wirtualny model, na podstawie którego przeprowadzono symulacje pracy roweru, wykorzystując program Working Model. Celem przeprowadzenia symulacji było określenie charakterystyki technicznej indywidualnego środka transportu. Przede wszystkim dokonano próby określenia prędkości, z jaką może poruszać się osoba jadąca „rowerem”, obliczenia, ile wynosi mak- symalny kąt wzniosu, po jakim może się poruszać, oraz średni wymagany nacisk na pedały. Model prototypu został przedstawiony na rysunku 12 .

Obserwując jazdę tradycyjnym rowerem, stwierdzono, że nacisk na pedały w początkowej fazie jazdy jest większy niż po rozpoczęciu ruchu. Na podstawie tej obserwacji została wyznaczona zależność, która określa siłę nacisku na pedały w chwili $t_{0}$ i jej późniejszy stopniowy spadek do 50\% wartości początkowej (rys. 13 i 14).

Symulacje zostały wykonane w kilkunastu wariantach, w których zmieniano parametry, takie jak nachylenie szyny, nacisk na pedały, wpływ dodatkowego obciążenia na parametry poruszania się indywidualnego środka transportu. Do przeprowadzenia symulacji przyjęto masę własną prototypu IŚT wynoszącą $40 \mathrm{~kg}$ oraz masę osoby poruszającej się ,rowerem” $-80 \mathrm{~kg}$.

Dodatkowo symulacje były przeprowadzane w dwóch odmianach kół - kolejno dla kół stalowych oraz dla kół stalowych w otulinie gumowej. Przykłady symulacji zostały przedstawione na rysunkach 15 i 16 . 
Na podstawie przeprowadzonych symulacji stwierdzono m.in., że zdecydowanie lepiej sprawdzają się koła w otulinie gumowej, ponieważ w przypadku kół stalowych rozpoczęcie ruchu wymaga znacznie więk- szej siły z powodu tarcia stali po stali. Ustalono także, że w przypadku zastosowania kół stalowych w otulinie gumowej maksymalne wzniesienie, po jakim może się poruszać IŚT, wynosi $10^{\circ}$.
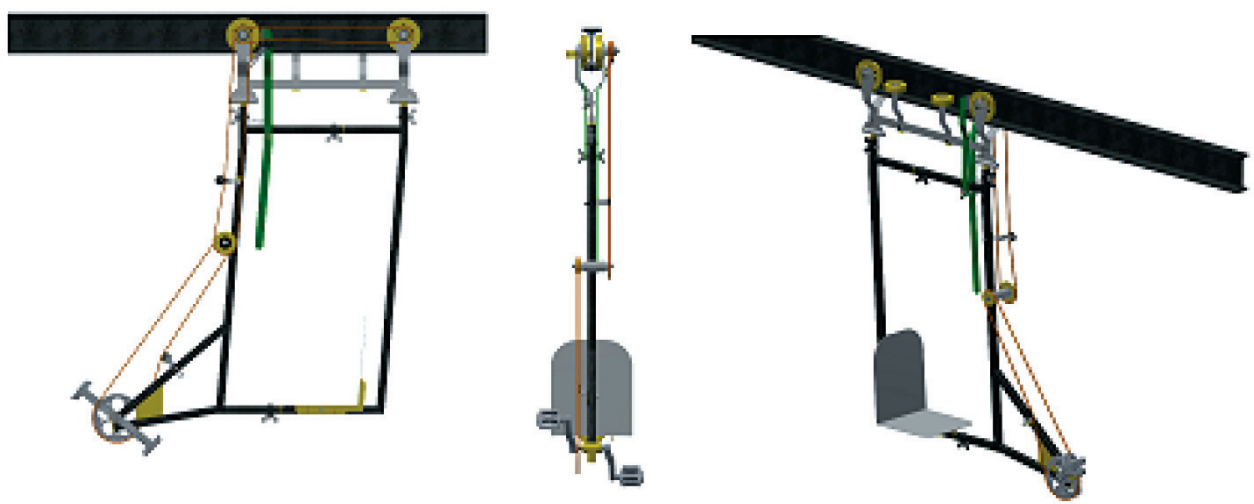

Rys. 12. Komputerowy model prototypu IŚT
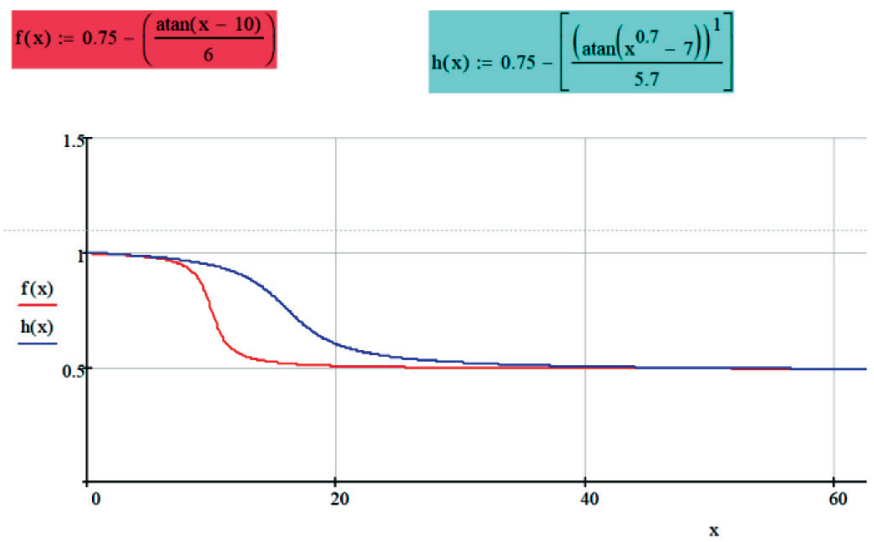

Rys. 13. Funkcja określająca sitę nacisku w czasie

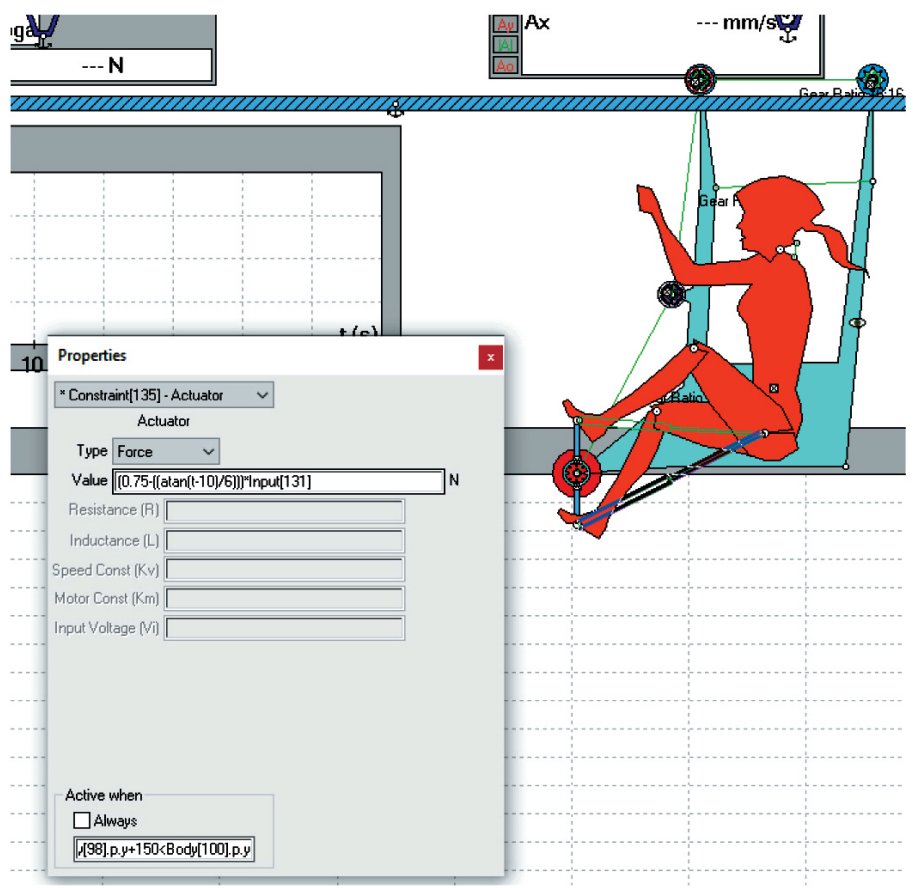

Rys. 14. Zastosowanie funkcji w programie Working Model 


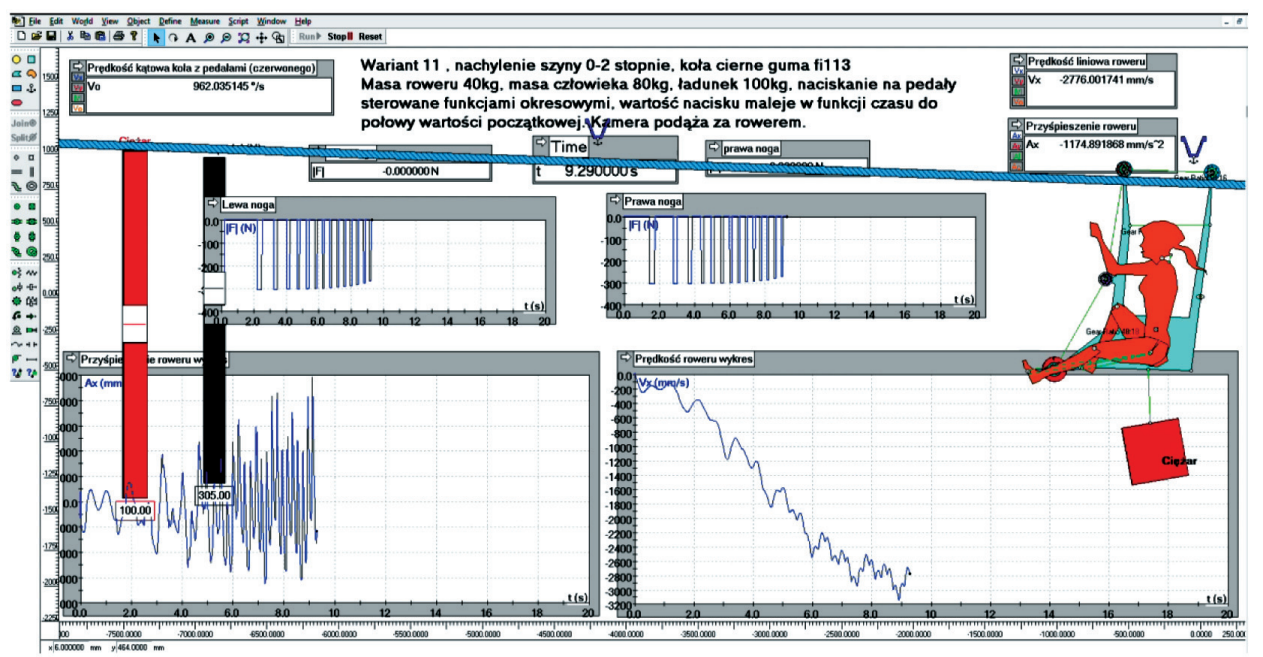

Rys. 15. Przykład symulacji z dodatkowym obciażeniem

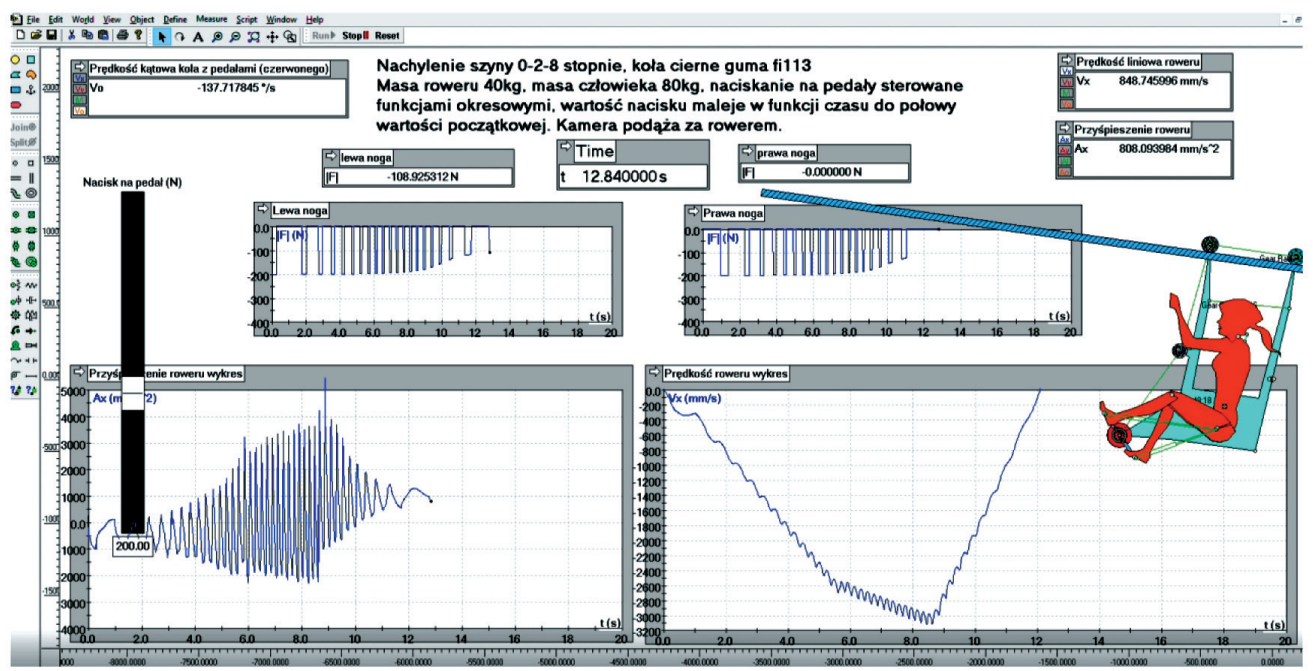

Rys. 16. Przykład symulacji wykonanej w programie Working Model

Pierwsze próby dołowe wykonano w kopalni Jastrzębie-Bzie ${ }^{2}$. Na podstawie obserwacji wyciągnięto następujące wnioski:

- Masa prototypu roweru (36 kg) jest za duża, aby była możliwość samodzielnego podwieszenia (bez pomocy drugiej osoby).

- Montaż segmentów roweru w całość jest możliwy do wykonania przez jedną osobę, ale dwie osoby wykonają go szybciej. Pod rozwagę należy wziąć przyspawanie do tba śruby pręta i wydanie wszędzie nakrętek motylkowych, tak aby nie było potrzeby używania dodatkowych narzędzi (kluczy).

- Po obciążeniu roweru masą osoby kierującej stabilność jest bardzo dobra (nisko umieszczony środek ciężkości minimalizuje ewentualne odchylenia boczne). Pedałowanie również nie wprowadzało dodatkowych bocznych wahnięć roweru.

- Należy wzmocnić ramiona, zabezpieczając przed wyłamywaniem dodatkowymi płaskownikami bocznymi.

\footnotetext{
2 https://www.youtube.com/watch?v=2IniLx2nJU8.
}

- Przeprowadzone próby pokazały, że do jazdy wystarczy napęd na jedno koło.

- Koła metalowe mają tendencje do poślizgu już na prostym odcinku.

- Próby przeprowadzono z dwoma przełożeniami na osi środkowej: 46/16 i 22/16 zębów w kołach łańcuchowych. Stwierdzono, że pierwsze przełożenie może wymagać nadmiernego wysiłku przy pokonywaniu wzniesień, natomiast drugie daje za małą szybkość przemieszczania się roweru. Optymalne będzie zastosowanie koła o pośredniej liczbie zębów - 34 lub 36.

Dokumentacja fotograficzna z prób dołowych została przedstawiona na rysunkach 17 i 18 .

Na podstawie drugich prób dołowych, które zostały wykonane w kopalni LW Bogdanka, wyciągnięto wnioski bardzo zbliżone do obserwacji przeprowadzonych w kopalni Jastrzębie-Bzie. Dodatkowo stwierdzono, że do dalszych prób należy rozważyć możliwość wyeliminowania kół bocznych prowadzących. 


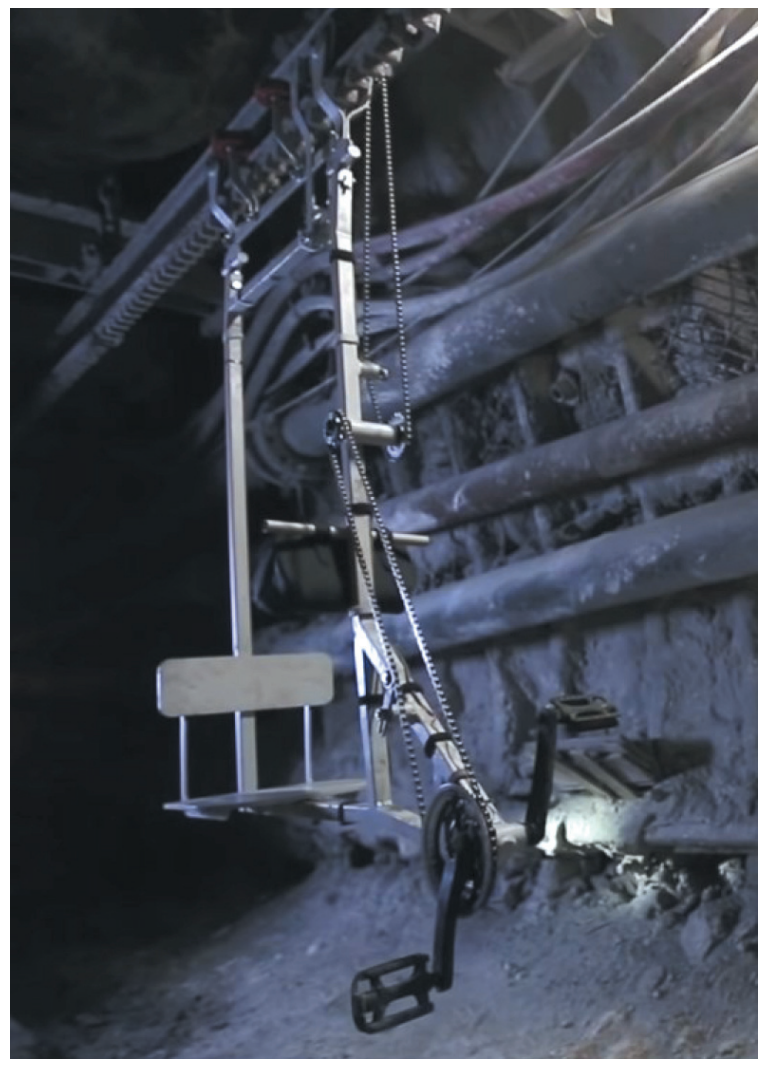

Rys. 17. Prototyp IŚT
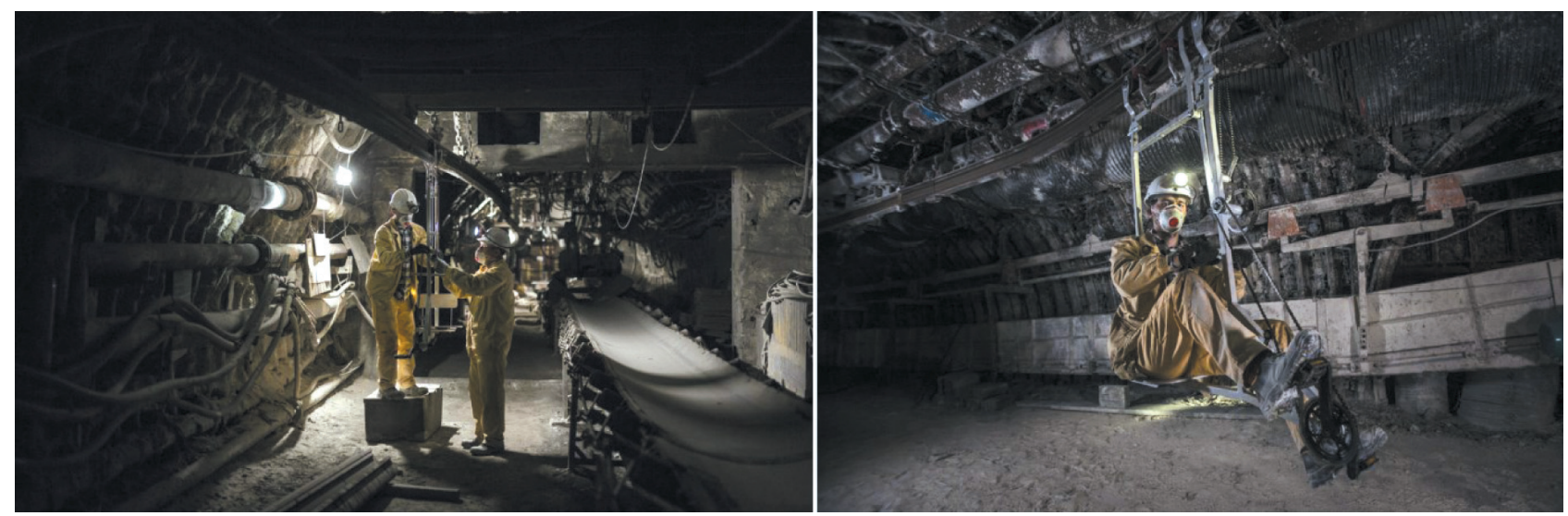

Rys. 18. IŚT podczas prób dołowych

\section{PODSUMOWANIE}

Urządzenie przeznaczone jest dla pracowników, którzy ze względu na specyfikę wykonywanej pracy często samodzielnie muszą pokonywać znaczne odległości podziemnymi wyrobiskami kopalń. Zastosowanie IŚT zdecydowanie ograniczy poziom zmęczenia pracowników oraz może mieć pozytywny wpływ na wzrost efektywnego czasu pracy.

Wykonany prototyp powinien być rozwijany w zgodzie $\mathrm{z}$ obowiązującymi przepisami oraz $\mathrm{w}$ porozumieniu z zainteresowanymi przedsiębiorstwami, tak aby jego użycie nie budziło wątpliwości co do użyteczności i bezpieczeństwa. Dalsza praca nad projektem IŚT skupia się nad możliwością zastosowania napędu elektrycznego lub hydraulicznego.

\section{Literatura}

[1] https://www.karldrais.de/?lang=en [20.04.2020].

[2] König, J.-G.: Fahrradfahren. Von der Draisinebiszum E-Bike, Reclam Verlag 2017.

[3] http://www.schwebebahn-wtal.de/tramenglish/indexgb.html [20.04.2020].

[4] Bianculli A.J.: Iron Rails in Garden State Tales of New Jersey Railroading, Indiana University Press 2008. 
[5] US Patent Office Specification forming part of Letters Patent No. 488,201, December 20, 1892.

[6] SCHARF. Materiały reklamowe - Grubendahrrader, Grubendahrrader 1955 .

[7] http://www.geocities.ws/draisinenl/scharffolder.html [20.04.2020].

[8] Krischer R.: Alweg-Bahn: Technik, Geschichte und Zukunft der legendären Einschienenbahn, Transpress 2013.

[9] Richards B.: New Movement in Cities, Sterling Publishing Company 1966.

[10] Lis A.J.: Rewolucja przemystowa w Europie, na ziemiach polskich i Górnym Ślasku, „Górnictwo - Perspektywy i Zagrożenia" 2016, 1(13): 314-322.

[11] Główny Instytut Górnictwa: Rowery kopalniane, „Nowości w Górnictwie" 1956, 13: 32.

[12] Volz V.: Mit Muskelkraft auf schaler Spur: Grubenfahrradaus Hamm, „Bahn-Express” 1994: 192-203.

[12] Heise-Herbst-Fritzche. Bergbaukunde; zweite band, Springer Verlag, Berlin - Heidelberg 1950.

[13] Patent PL P.418208 „Środek transportowy z własnym napędem do kolejki podwieszonej". mgr inż. KAZIMIERZ KUŹMA

KRZYSZTOF PYREK

mgr inz. WOJCIECH KOCIK

mgr inż. PIOTR KALINOWSKI

Przedsiębiorstwo Budowy Szybów S.A.

ul. Hutnicza 5-9, 42-600 Tarnowskie Góry

\{kkuzma, kpyrek, wkocik pkalinowski\}@.jswpbsz.pl

dr inż. PAWEŁ KAMIŃSKI

Przedsiębiorstwo Budowy Szybów S.A.

ul. Hutnicza 5-9, 42-600 Tarnowskie Góry AGH Akademia Górniczo-Hutnicza

im. Stanistawa Staszica

al. Mickiewicza 30, 30-059 Kraków

pkaminski@jswpbsz.pl,pkamin@agh.edu.pl 